\title{
SURVEY
}

Rudolf Dekker

\section{LABOUR CONFLICTS AND WORKING-CLASS CULTURE IN EARLY MODERN HOLLAND ${ }^{1}$}

SUMmARY: From the 15th to the 18th century Holland, the most urbanized part of the northern Netherlands, had a tradition of labour action. In this article the informal workers' organizations which existed especially within the textile industry are described. In the 17th century the action forms adjusted themselves to the better coordinated activities of the authorities and employers. After about 1750 this protest tradition disappeared, along with the economic recession which especially struck the traditional industries. Because of this the continuity of the transition from the ancien régime to the modern era which may be discerned in the labour movements of countries like France and England, cannot be found in Holland.

One day in April 1696 in Amsterdam a number of sailors met in an alehouse just outside the city. They were celebrating their last day ashore. They adorned their hats with green leaves, and made one banner from a tar brush and a mat, and another from a stick and a white handkerchief. The merry company of some fourteen men then entered the town. Singing, they marched along, attracting the attention of bystanders. Such behaviour, however, was not appreciated by the municipal authorities. After a while the crowd was dispersed by the bailiff and his men. They arrested two young sailors, one from Stockholm, the other from Hamburg. Three days later they were sentenced to be whipped and banished. ${ }^{2}$

This seems, even by seventeenth-century standards, a heavy punishment for an innocent parade of sailors who wanted to enjoy their last day on shore before leaving for the long and dangerous voyage to the East Indies. The judges, however, were of the opinion that they had intended to start a riot. Sailors had a reputation for rebelliousness, and, indeed, the group had been

${ }^{1}$ This article is an extended version of Rudolf Dekker, " 'Getrouwe broederschap': Organisatie en acties van arbeiders in preindustrieel Holland", Bijdragen en Mededelingen betreffende de Geschiedenis der Nederlanden, 103 (1988), pp. 1-19.

${ }^{2}$ Gemeentearchief (hereafter, GA) Amsterdam Rechterlijke Archief (hereafter, RA) 343, folios $52 \mathrm{ff}$. 


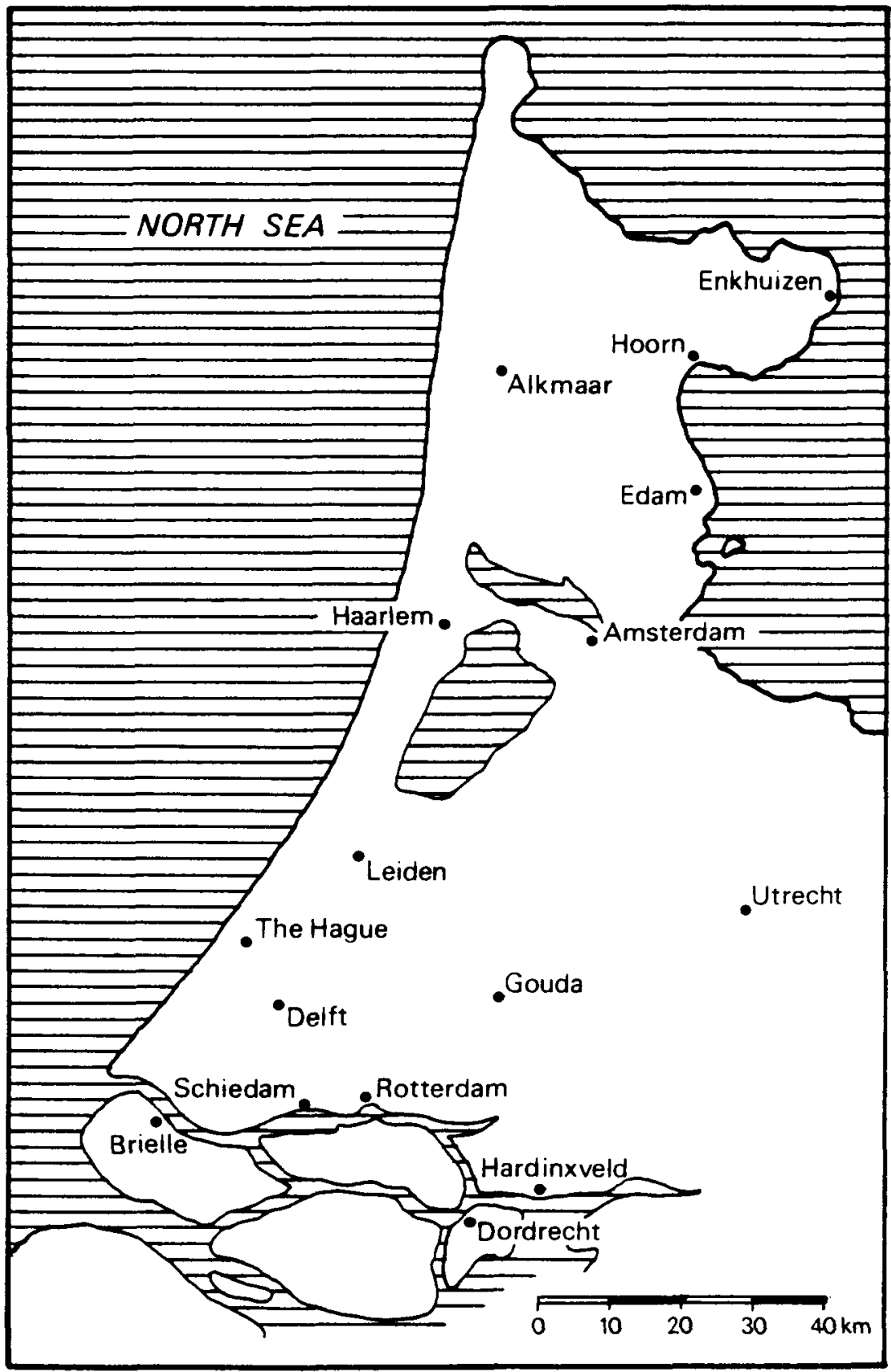

The western part of the Netherlands (c. 1650). 
heading for the head office of the East India Company, the merchant company that employed them.

This little scene was not exceptional. On several occasions in Amsterdam conflicts between sailors and both the East India and West Indies Companies had developed into riots. And it was not only sailors who were involved in such brawls; conflicts between workers and employers were a regular phenomenon in preindustrial Holland. This is not surprising. The Netherlands was already highly urbanized and industrialized in the late Middle Ages. At the same time shipping had grown to be a big business, which, especially in the seventeenth and eighteenth centuries, employed thousands of men. The early-modern Netherlands is therefore well suited to a study of the development of labour relations, the mobilization and protests of workers, and the political culture of the labouring classes in general. This article is geographically restricted to the county, and - after the establishment of the Dutch Republic - province of Holland, and concentrates on the period from around 1300 to around 1800 .

Until recently historians have tended to neglect the study of labour relations in preindustrial Europe. Influential historians of preindustrial popular protest, like George Rudé, thought that previously food riots and tax revolts were far more important than strikes. ${ }^{3}$ And furthermore, "early" strikes, before the middle of the nineteenth century, were characterized as being far more disorderly than well-organized modern strikes. Eric Hobsbawm therefore introduced the expression "collective bargaining by riot". ${ }^{4}$ According to some historians, strikes before the industrial revolution were simply impossible, if only because the patriarchal system of labour relations of the ancien régime prevented workers from equating work with wages. When they stopped working they did so not in order to withdraw their labour, but to be free to engage in old-fashioned forms of protest, like a disorderly march through the city. ${ }^{5}$

The renewed interest in preindustrial labour relations is still strikingly backward looking. When in 1979 Steve Kaplan used the expression "prehistory of the proletariat", ${ }^{6}$ he confirmed that historical interest until then was

${ }^{3}$ George Rudé, The Crowd in History. A Study of Popular Disturbances in France and England 1730-1848 (New York, 1964), p. 6, and especially ch. 4, "Labor disputes in eighteenth-century England", pp. 66-79.

${ }^{4}$ E. J. Hobsbawm, Labouring Men. Studies in the History of Labour (London, 1978), p. 7, Primitive Rebels. Studies in Archaic Forms of Social Movement in the 19th and 20th Centuries (Manchester, 1978), p. 7.

${ }^{5}$ W. M. Reddy, "The Textile Trade and the Language of the Crowd at Rouen 17521871", Past and Present, 74 (1977), pp. 62-89; cf. W. M. Reddy, The Rise of Market Culture. The Textile Trade and French Society, 1750-1900 (Cambridge, 1984), especially ch. 5 .

"S. Kaplan, "Réflexions sur la police du monde du travail, 1700-1815", Revue Historique, 103 (1979), pp. 17-77. 
largely a search for the origins of the modern labour movement. This explains also why research seldom goes further back than the eighteenth century. Furthermore, it is logical that the first studies should have been mainly descriptive, like C. R. Dobson's Masters and Journeymen, about England, bearing the telling subtitle "A Prehistory of Industrial Relations". 7 The articles about France by Kaplan and Gayot are equally packed with information. An important study of the German situation was published by Andreas Griessinger, who favoured a more analytical approach, using ideas of Habermas and other sociologists. He systematically criticized the ideas of Hobsbawm and others, and made clear that preindustrial strikes involved considerable preplanning, that they were often peaceful, and usually far from local in scope. ${ }^{8}$

Only very recently historians tend to set preindustrial strikes in a wider context. Michael Sonenscher has made clear that French workers in the eighteenth century frequently had recourse to the law as a weapon. New approaches have been borrowed from anthropology and the history of mentalities. In these the emphasis is placed on meaning, ritual, ideology, and language. ${ }^{9}$ A recent collection of essays, edited by Patrick Joyce, shows the potential of these approaches, but also reveals the tentative state of this type of research. ${ }^{10}$ Likewise, it is too early to expect comparative studies based on these new insights, although a short survey by David Geary may temporarily fill this gap. ${ }^{11}$ The aim in this article is mainly to give

${ }^{7}$ C. R. Dobson, Masters and Journeymen. A Prehistory of Industrial Relations, 17171800 (London, 1980).

${ }^{8}$ A. Griessinger, Das symbolische Kapital der Ehre (Ulm, 1981); cf. Rainer S. Elkar (ed.), Deutsches Handwerk in Spätmittelalter und früher Neuzeit. Sozialgeschichte Volkskunde - Literaturgeschichte (Gottingen, 1983), and Hans-Ulrich Thamer, "On the Use and Abuse of Handicraft: Journeymen Culture and Enlightened Public Opinion in 18th and 19th Century Germany", in Steven L. Kaplan (ed.), Understanding Popular Culture. Europe from the Middle Ages to the Nineteenth Century (Berlin, New York and Amsterdam, 1984), pp. 275-300.

${ }^{9}$ William H. Sewell, Work and Revolution in France: The Language of Labor from the Old Regime to 1848 (Cambridge, 1980); for a critique of this see Lynn Hunt and George Sheridan, "Corporatism, Association and the Language of Labor in France, 17501850", Journal of Modern History, 58 (1986), pp. 813-844; Michael Sonenscher, "Journeymen, the Courts and the French Trades 1781-1791", Past and Present, 114 (1987), pp. 77-109, "Mythical Work: Workshop Production and the Compagnonages of EighteenthCentury France", in Patrick Joyce (ed.), The Historical Meanings of Work (Cambridge, 1987), pp. 31-63, The Hatters of Eighteenth Century France (Berkeley, 1987), Work and Wages: Natural Law Politics and the 18th-Century French Trades (Cambridge, 1989), and J. Rule, The Experience of Labour in 18th-Century Industry (London, 1981). See also the essays contained in S. L. Kaplan and C. J. Koepp (eds), Work in France, Representations, Meanings, Organization and Practice (Ithaca, 1986).

${ }^{10}$ Joyce, The Historical Meanings of Work.

${ }^{11}$ Dick Geary, "Protest and Strike: Recent Research on 'Collective Action' in England, Germany, and France", in Klaus Tenfelde (ed.), Arbeiter und Arbeiterbewegung im Vergleich (Munich, 1986), pp. 363-387. 
an account of labour relations in Holland from the fifteenth to the eighteenth centuries. It is also meant as a plea for a historical-anthropological and, especially, a comparative approach to the study of labour relations. Finally, it argues that labour historians should see the eighteenth century not a priori as a period of "prehistory". As will be shown, labour protest in Holland even then had a history going back many centuries, and the eighteenth century may better be called a period which saw the decay of traditional working-class power than the birth of the modern labour movement.

\section{Introduction}

Since the thirteenth century the Netherlands was one of the main centres of urbanization in Europe. Initially, industry and commerce flourished mainly in the cities of the South, especially in Flanders and Brabant. There soon followed a slow shift towards the north. In the fourteenth century the cities of Holland began to develop. Some cities, like Dordrecht, Amsterdam and Enkhuizen, became commercial centres and harbours for the commercial and fishing fleets. Other cities became industrial centres. Delft and Gouda produced beer, other towns developed shipbuilding industries. In the seventeenth century, after the establishment of the Republic, some cities developed new industries: Delft became a centre of pottery, Gouda produced earthen pipes, Schiedam liquors, while Amsterdam became a centre for sugar refining and, later, cotton printing. Besides the introduction of new industries, the character of some of the old industries changed. In some cases production was modernized, for instance through mechanization, like wood sawing using the power generated by windmills. Changes could also occur in labour relations, because in some trades guild and government regulations were weakened; this was the case with the potters in Rotterdam, who in 1640 were allowed to take on as many journeymen as they pleased.

Throughout the fourteenth to the eigthteenth centuries, the most important industry in Holland was the textile industry. This industry was made up of a great number of smaller trades. The raw materials varied, the processes of production were complicated, and there were many finishing industries. In the course of time Leiden became the most important textile-producing city in Holland. Specialization and the division of labour had progressed greatly, especially in the production of woollen cloth. Sorting and washing wool, combing, spinning, weaving, fulling and dying were only the main stages in the process. The material passed through the hands of at least twenty different workers, and the final product was bought by merchants, who exported most of it throughout Europe. 
In the Middle Ages all work was done by artisans in small workshops. However, the cloth industry was the first to adopt a capitalist pattern of production. Some weavers became drapers, who controlled the successive stages in the production of cloth. Drapers bought raw wool from merchants, and later on sold them the finished cloth. Thus the draper became an entrepreneur who financed and organized the whole process of production. Spinners, weavers and fullers became dependent on the drapers.

The cloth industry combined this modern, capitalist, character with many medieval features. Guild and town regulations were strict, and there were, for instance, limitations on the number of jouneymen that a draper was allowed to employ, and enforced limits on the use of mechanical devices such as mills.

After having flourished in the fourteenth and fifteenth centuries, the Leiden textile industry underwent a period of severe and prolonged crisis in the sixteenth century. This was partly caused by the political disturbances during the Revolt against Spain. After 1600, however, the industry was regenerated. The political situation was stabilized, and many immigrants from the southern part of the Netherlands brought new entrepreneurial energy to the country. From now on another type of cloth was produced. It was lighter and was produced in a new way. Fulling was now done mechanically. Around 1630 a new type of entrepreneur replaced the old-fashioned draper: the reder. Like the draper, the reder controlled the whole process of production. But his grip on the workers was stronger. Master artisans were now reduced to mere middlemen. Reders owned relatively large workshops in which as many as forty workmen worked together. Shearing, especially, was carried out in such workshops. Shearing was from now on the most important stage in the process of production of woollen cloth. It was done by shearers, who were the best educated and best paid workers in the whole textile industry. The importance of their position is confirmed by a seventeenth-century painting in which all the stages of the manufacturing process are depicted: the shearers are the only workers who wear burger coats and hats. ${ }^{12}$

In the second half of the seventeenth century Leiden had some 70,000 inhabitants. At least half of them worked in the textile industry. After around 1670 decline set in, at first only slowly. In 1749 the population of the city numbered less than 40,000 inhabitants. In 1798 only 27,000 were left; of these, 9000 were dependent on poor relief. Leiden had become an almost desolate city.

12 The painting hangs in the Centraal Museum, Utrecht, and is reproduced in Ach Lieve Tijd (Haarlem, 1986), p. 83. 
Amsterdam was also an important industrial town, though its reputation as a commercial city has sometimes led historians to forget this. In the Middle Ages Amsterdam was still a small town, although it had its own textile industry. Its growth began around 1600 . In the middle of the seventeenth century the town had 200,000 inhabitants. Its economy was much more diverse than that of Leiden. The textile industry was important, but there were also shipyards, breweries, sugar refineries, and an important building industry. It was also Holland's largest port. The sailors who crowded into the city, especially in spring and autumn - before their departure and after their arrival - constituted a large proportion of the city's proletariat. In the seventeenth century the production of cloth suffered the same decline as in Leiden, but in the early eighteenth century new textile industries flourished, like cotton printing.

In Dutch cities the textile industry was tightly organized from above. In Leiden, for example, the textile industry was organized into guilds and, more importantly, neringen. There were no guilds of weavers, dyers, or spinners; the only guilds were those of shearers, wool combers and fullers. Only master artisans were members, but journeymen and apprentices also fell under the guild regulations. One of the functions of these guilds was to regulate conflicts over wages and working conditions. How little influence journeymen had within a guild is shown by an example from Amsterdam in 1630. Some journeymen carpenters petitioned their guild for a wage rise. They were aware that they were doing something impertinent, and the petition therefore took the form of a round robin in order to disguise the order of the signatures and the extent of individuals' responsibility. Nevertheless, the case went before the courts, and the journeymen were sentenced. ${ }^{13}$

More important were the neringen. There were seven leading textile branches. The most important nering regulated the production of laken (cloth). A nering was a guild-like organization, except that it was founded by the city government. Each nering had a governing board, composed of two superintendents, appointed by the magistrate, and a few governors, appointed by the mayor on the recommendation of the most important manufacturers within each nering. A nering was supposed to regulate all kinds of disputes. Master artisans, journeymen and apprentices all fell under a nering. For instance, weavers who produced cloth fell under the cloth nering. Other weavers fell under other neringen, according to the type of textile they produced. Guilds united those who did the same kind of work, although they sometimes subdivided their members according to

${ }^{13}$ W. F. H. Oldewelt, "De zelfkant van de Amsterdamse samenleving en de groei der bevolking", Tijdschrift voor Geschiedenis, 77 (1964), pp. 39-56 (GA Amsterdam RA 298 , folio $157 \mathrm{v}$ ). 
type of work or the raw material they used. A nering, on the other hand, united those who were involved in producing the same type of cloth. The difference is essential. More than guilds, neringen were part of the system of municipal government. Groups of workers, who otherwise would be united in a guild, were now split. This was a conscious policy of the municipal government of Leiden. In the middle of the seventeenth century, Pieter de la Court, a Leiden cloth manufacturer and famous as a writer of political tracts, was of the opinion that the more the population of the city was divided, the better the city could be governed..$^{14}$ In Leiden the guilds of shearers, combers and fullers all fell under the laken-nering, because these three types of work were peculiar only to the production of laken.

The weak position of the guilds in Holland is in remarkable contrast to their position in the south of the country. In cities like Ghent, Douai, Liège in the fourteenth century, guilds even acquired political power, occasionally through revolution. In many cities of the Eastern provinces of the Netherlands, guilds were also sometimes influential, like in Utrecht and Groningen. In Holland guilds developed later, at a time when both local and central power (the Counts of Holland) were relatively firmly established. The only city in Holland where guilds had some political influence was Dordrecht, and it is no coincidence that this was the oldest city and can therefore be compared with its neighbours in Flanders. Everywhere else the guilds were effectively curbed, and in Leiden for some time they were even forbidden. Since the fourteenth century it had always been governmental policy in Holland, both at the central level and the municipal level, to keep guilds powerless. Towards journeymen governments acted even more severely. They were generally forbidden to form their own associations; there developed no compagnonnages or frèreries in Holland. And repression went even further than that. All forms of public expression of their own identity were banned. Thus, for instance, in Haarlem porters of corn were in 1598 forbidden to celebrate their traditional feast of "bringing out the ship of St. Reynuit". St. Reynuit was a "mock saint" and such a carnavalesque custom was regarded with disfavour by the new, reformed government. ${ }^{15}$

Only in the seventeenth and eighteenth centuries did a form of organization develop among journeymen; this was the bos (box). In a bos journeymen were brought together and contributed weekly sums to a box in return for the right to receive an allowance in case of illness, or funds for a decent burial in case of death.

${ }^{14}$ F. Driesen (ed.), Pieter de la Court, Het welvaren van Leiden (Leiden, 1911), p. 160. On De la Court see E. O. G. Haitsma Mulier, The Myth of Venice and Dutch Republican Thought in the Seventeenth Century (Assen, 1980).

is GA Haarlem RA 66-I, folio 179. 
The two largest groups of wage labourers in the seventeenth and eighteenth centuries were sailors and soldiers. Both sailors and soldiers worked on a contract basis. ${ }^{16}$ Soldiers received a small sum when signing their contract, and were thereafter paid regular wages. Conflicts over payment were common enough in preindustrial Europe, and they not seldom escalated into mutinies. However, in the Dutch Republic soldiers were usually well paid and on time, and mutinies were exceptional. ${ }^{17}$ Conflicts among sailors were much more common. Sailors were employed by the fishing and commercial fleets, and in the navy; the biggest employers were the West Indies and East India Companies and the navy. All three had a reputation for being slow payers, and protests ashore or aboard, including mutinies, were a constant threat. Nevertheless, sailors cannot be put on a par with industrial workers. For the majority, seafaring was only intended to be a temporary occupation, with the objective of settling ashore afterwards. In addition, sailors saw themselves, and were seen, as a very distinct group within Dutch society. They had a distinctive argot, dress and walk, for example.

In short, although the working class of Holland from the fourteenth to the eighteenth centuries was heterogeneous, it is obvious that labour relations could easily form a source of conflict. These conflicts, however, should be seen within the specific economic, social, and political contexts of Holland, especially at the time of the Dutch Republic. The traditional picture of general economic development in Holland may be summarized as one of decline in the sixteenth century, a Golden Age in the seventeenth century, decline again in the eighteenth century, followed by stagnation during most of the nineteenth century. Recent research has questioned especially the evidence of decline in the eighteenth century, and of stagnation in the nineteenth century. Banking, for instance, remained important in the eighteenth century. In addition, the continuing importance of the agrarian sector since the sixteenth century needs to be considered..$^{18}$ Another discussion has focused on wages in Holland, which were usually higher than elsewhere in the Dutch Republic or in neighbouring countries. This

${ }^{16}$ See Marcus Rediker, Between the Devil and the Deep Blue Sea: Merchant Seamen, Pirates, and the Anglo-American Maritime World 1700-1750 (Cambridge, 1987).

${ }^{17}$ A minor incident happened in 1702 when some twenty soldiers gathered before the town hall of Den Haag to protest about the non-payment of wages due to them (Algemeen Rijksarchief (hereafter, ARA) Hof van Holland 5658, folios 218-219).

${ }_{18}$ For an overview see J. L. van Zanden, "De economie van Holland in de periode 1650-1805: Groei of achteruitgang? Een overzicht van bronnen, problemen en resultaten", Bijdragen en Mededelingen voor de Geschiedenis der Nederlanden, 102 (1987), pp. 562-609. Important contributions to the discussion have been made by English and American authors such as Jan de Vries, J. C. Riley, R. T. Griffiths, and Jonathan Israel. For a guide to the English literature on the Netherlands in general see P. K. King and M. Wintle, The Netherlands (World Bibliographical Series, vol. 88 (1988)) 
factor undoubtedly made the North Sea coast area attractive for immigrants. ${ }^{19}$

The social outlook of Holland during the time of the Republic differed greatly from that of most other European countries. Although there was no powerful class of land-owning nobility, the few noble families in Holland succeeded in preserving their social and political status. Nevertheless, the regentenpatriciaat, the burgher families who held power in the city governments, and also in the States of Holland, formed the real elite of the country. The contrast between the wealthy and the poor was sharp, but not as sharp as elsewhere. In the countryside there was a large class of well-todo farmers, and in the cities the middle classes were sizeable.

With respect to its political structure the Dutch Republic was also an anomaly in Europe. The seven provinces formed a union, in which the province of Holland was the most powerful. Power was to a large extent decentralized. The provinces, and within the provinces the cities, remained autonomous in many respects. The office of Stadtholder, for long periods held by the Princes of Orange, was a relic of the former monarchical state, and formed another centre of power. Nevertheless, the Dutch state functioned well, and, according to recent historical research, did so even better than contemporaries realized. Indeed, nowhere in Europe were higher levels of taxation successfully levied, and nowhere was there a better organized standing army. Although the municipal governments in theory allowed for some degree of democracy and influence for the burghers, in practice public offices were the monopoly of a small group of wealthy regenten. This select group coincided largely, though not always completely, with the monied classes. Their professional background was more likely to have been banking and trade than manufacturing. In the course of time the regenten became a more professional governing class, and a law study became a matter of course for their future members.

Finally, the Republic was not as free from unrest as is generally thought. Several major waves of political protest took place, and were usually aimed - as in 1672 and 1747 - at restoring the stadtholders to power. Tax revolts also took place frequently, and, to a lesser extent, so did food riots. These disturbances were usually efficiently suppressed. The fact that the government could rely on a loyal standing army was an important factor in maintaining public order. Although great outbursts of collective violence were exceptional, they tended to make a lasting impact on the memory of the population. The labour disputes that we shall analyze differed in many ways from other forms of collective protest, but they cannot be seen without reference to this broader background. ${ }^{20}$

19 Jan Lucassen, Migrant Labour in Europe 1600-1900: The Drift to the North Sea (London, 1987). 


\section{The uitgang in the Middle Ages}

Although our sources are scarce for the fourteenth to the sixteenth centuries, there is enough evidence to conclude that clashes between workers and employers were not unusual, at least within the textile industry. The fullers were by far the most active group of workers. Their work was heavy and dirty, but it was essential to the production of woollen cloth. The fullers were dependent on drapers. Both master artisans and journeymen had thus become more or less wage workers. Fullers and drapers therefore confronted each other as workers and employers. In these conflicts, however, there was a third party: the city government. Because labour relations in the textile industry were regulated in great detail from above, the city government was necessarily involved in all changes in working conditions. Further responsibility for public order could involve the city government in a dispute. The most severe conflicts ended with the fullers leaving a city until their demands were complied with. It is telling that the Dutch language even had a specific word for such a protest - uitgang. Between 1371 and 1478 at least eleven uitgangen were staged by fullers in Leiden, Amsterdam, Den Haag and Haarlem..$^{21}$ The aim of this was to escape the jurisdiction of the local judicial authorities. The fullers went to other cities, sometimes even to cities outside the county of Holland. In 1472 the fullers from Haarlem traveled to the city of Kampen, which lay some 120 kilometres away and fell under the jurisdiction of the Bishop of Utrecht. That was a considerable distance at that time: it took the beadle of the city of Haarlem six days to deliver a letter to the fullers.

The uitgang of the fullers of Leiden to the city of Gouda in 1478 is exceptionally well documented. Even the correspondence between the fullers and the city government has been preserved. Although the distance between Leiden and Gouda was no more than twenty kilometres, negotiations also then took place by letter. The first letter of the fullers contained a

${ }^{20}$ See issue 2 of the Tijdschrift voor Sociale Geschiedenis, 15 (1989), which was devoted to the role of collective protest in the history of the Netherlands. See particularly, Charles Tilly, "History, Sociology, and Dutch Collective Action", pp. 142-158, and Rudolf Dekker, "Some remarks about collective action and collective violence in the history of the Netherlands", pp. 158-165. See also R. M. Dekker, Holland in beroering. Oproeren in de 17de en 18de eeuw (Baarn, 1982).

${ }^{21}$ N. W. Posthumus (ed.), Bronnen voor de geschiedenis van de Leidsche textielnijverheid (hereafter, LTN) 6 vols ('s-Gravenhage, 1910-1922), I, nos 15, 27, 28, 122, 130 , 154-158, 508-524 and 527-529; J. G. van Dillen (ed.), Bronnen tot de geschiedenis van het bedrijfsleven en het gildewezen van Amsterdam 1512-1672, 3 vols ('s-Gravenhage, 1929-1974), I, nos 1214 and 1216; GA Haarlem Stad, I, nos 190 and 236, and cf. 442; H. E. van Gelder, "De 'draperye' van Den Haag", Jaarboek Die Haghe 1907, pp. 229-351, and cf J. van Herwaarden, Opgelegde bedevaarten (Assen, 1978), p. 350 for details about an ordinance against uitgangen in Schiedam. 
list of thirty-four demands. After three months of negotiations, the fullers returned to Leiden. The most important issue was wages. However, the drapers at first refused to pay higher wages. They wrote to the fullers: "You can take what we offer or you can go hungry this winter." Eventually, the drapers and the city government agreed to some of their demands. The letters of the fullers show a strong sense of self-confidence. They referred to the success of earlier uitgangen which had been "staged by our forefathers". This expression is important, because it shows that the fullers were aware of using a tactic which had proven its value in the past. One can even say that they were consciously acting within an established tradition of labour protest.

Besides the eleven successful uitgangen there are also several documented examples of protests which failed early on. In a few cases the fullers went no further than to organize a general meeting outside a city. Such meetings were obviously intended as a first step to an uitgang. In one case, in 1470, some Leiden fullers used the traditional feast of the fullers on Shrove Tuesday as a cover to plan an uitgang. This time details of their plans leaked out and they were never put into effect.

Other groups of textile workers also occasionally came into conflict with their employers. ${ }^{22}$ However, only the weavers of Amsterdam in 1523 organized an uitgang..$^{23}$ It was more usual simply to stop working until their demands were fulfilled, to go on strike without leaving a city. The dyers of Leiden, for instance, decided in 1462 to stop working, "because they did not want to work for these wages; they wanted to receive more". In Leiden, the dyers were regarded as the most active group after the fullers. ${ }^{24}$

An uitgang or a strike necessitated some degree of organization in order to be successful. Again and again we read, especially in the criminal records, about unions, conspiracies, monopolies or secret agreements of which the participating workers are accused. Although details are lacking we can assume that these accusations contain a degree of truth. Such well-organized protests like uitgangen or strikes must have been carried out with some form of organization. For one thing, it was important that all workers showed solidarity. And if needed, participants enforced solidarity upon their comrades. During a strike in Leiden in 1537 the weavers shouted "if anyone works they will be found and their work destroyed". During another strike, some years later, the government was confronted by the fact

${ }^{22}$ In Delft in the first half of the fifteenth century weavers were forbidden to hold meetings; cf. Emilia Maria Anna Timmer, Knechtsgilden en knechtsbossen in Nederland. Arbeidersverzekering in vroeger tijden (Haarlem, 1913), p. 7, and R. Fruin, Het oudste der tot dusver bekende keurboeken van Delft, pp. 71 and 74 .

${ }^{23}$ Van Dillen, Bronnen Amsterdam, I, no. 73.

${ }^{24}$ LTN I, no. 508; cf. no. 620. 
that weavers who wanted to work were forced to stop "for fear that they would lose their reputation, if they continued to work". 25

During the Middle Ages the militancy of workers in the textile industry seems to have been unique. At first sight an exception might seem to have been the brewers of Gouda, who in 1371 organized an uitgang. ${ }^{26}$ But this was probably the action of a whole trade against measures enforced by the local government. Such protests were not uncommon. In 1479, for instance, bakers in Amsterdam went on strike to protest against the low official bread price, the level of which was decreed by the government.$^{27}$ In 1576 butchers in Rotterdam went on strike to protest against a new tax, as did the innkeepers of Leiden in $1602 .{ }^{28}$ That such conflicts did not always divide employers and workers is shown by a case in Dordrecht in 1651. The smiths closed their shops, protesting against an unfavourable government decision. During this strike, the masters paid their journeymen an allowance. ${ }^{29}$ This type of conflict between a whole trade and local authorities disappeared after the middle of the seventeenth century, or, rather, such conflicts no longer took on the form of a strike.

During the sixteenth century the militancy of workers diminished. The fullers particularly became quiescent. Their very last protests took place in Leiden in 1619 and $1621 .^{30}$ Their behaviour then had nothing in common with their self-confidence of one or two centuries before. They simply marched through the streets with a banner, made from an apron, and a drum, made of a cask. The city officials were little disturbed by this demonstration, and described it merely as a street brawl. This riotous demonstration differed greatly from the rational uitgangen they once organized.

What had changed during the course of the sixteenth century? To begin with, the religious and political conflicts, and the Revolt against Spain, had brought other issues to the fore. For a time religious and political conflicts more easily inflamed people than labour disputes. Furthermore, poor exiles from Flanders, many of whom were experienced in some form of textile production, enlarged the labour reserve greatly. There were also more specific reasons. Firstly, there was the general decline in the Dutch textile industry which affected traditional militancy. Secondly, the method of producing woollen cloth had changed. Fulling was more and more

25 LTN II, no. 1076.

${ }^{26}$ Dick Edward Herman de Boer, Graaf en grafiek. Sociale en economische ontwikkelingen in het middeleeuwse "Noordholland" tussen 1345 and 1415 (Leiden, 1978), p. 284.

${ }_{27}$ A. J. M. Brouwer Ancher, De gilden ('s-Gravenhage, 1895), p. 142.

28 "Stakende vleeshouwers in 1576", Rotterdams Jaarboekje 1922, p. 98; GA Leiden RA $3-5$, folios $225 \mathrm{ff}$.

${ }^{29}$ GA Dordrecht manuscript 135a.

${ }^{30}$ LTN II, nos 79, 80 and 87. 
frequently being done mechanically with mills. For this reason, and also because a lighter type of cloth was produced, the fullers had lost their central position in the textile industry. It is no coincidence that around 1620 many fullers left their job and chose to join the army. Becoming a soldier at that time was usually the result of a decision made out of desperation.

There was yet another reason why labour militancy diminished: the changing attitude of the authorities. Participation in an uitgang or strike was from the beginning considered a crime, because for a journeyman to refuse to work meant breaking his contract. Later on, more specific decrees were issued by the city governments which explicitly declared such protests to be criminal. The punishments mentioned in these decrees became more severe in the course of time. In 1391 in Leiden the penalty for joining an uitgang was banishment for a period of two years. In 1447 this was changed to the death penalty. Furthermore, from 1435 all fullers in Leiden were obliged to swear an oath that they would not participate in any rebellion. In Amsterdam in 1473 a decree was issued which not only forbade uitgangen but also any meeting of fullers. The innkeepers who allowed such meetings to take place in their inns were threatened with the amputation of their right hand, or a fine.

This development was also reflected in judicial practice. The judicial archives contain details of several sentences handed out in this period. These sentences became more and more severe, and after 1447 there was a case in Leiden where the death sentence was indeed pronounced, although this was, after a plea for clemency, revised to a spell in the pillory, an enforced pilgrimage, and banishment for life.

The increasingly severe attitude of city governments was no isolated process. It reflected the more general tightening of the grip of the government on the populace, which resulted in a growing stream of decrees affecting public order. Central government also became more powerful. In the fourteenth century, when Holland was still an independent county, central government was relatively weak. In the fifteenth and sixteenth centuries the county of Holland was part of the Burgundian and later of the Habsburg Empires, until it became one of the seven provinces constituting the Dutch Republic. The dukes of Burgundy were powerful state builders, and on occasions they took measures directed against striking workers. In 1459 Duke Phillipe urged the Amsterdam fullers to return to the city. In 1472 the law court of Haarlem asked Duke Charles to help settle a conflict between fullers and drapers. A year later the Duke published an explicit ban on uitgangen, in response to a protest by fullers in Amsterdam. Although Holland was divided into a large number of territorial jurisdictions, such a ducal decree gave more weight to local law throughout the whole county. However, during the Middle Ages the central government was not powerful enough, or the Burgundian dukes did not think it worthwhile, to 
take direct action in local labour disputes. This changed after Holland became a province within the Dutch Republic.

\section{The change from uitgang to strike}

Around 1600 important changes in the Dutch cloth industry had brought a new elite of workers to the fore: the shearers. They were responsible for the finishing processes in the production of woollen cloth and especially for the gloss for which Dutch cloth became famous. The result can still be admired in many Dutch portrait paintings of the Golden Age. Shearers followed an apprenticeship for four years, and they were the most schooled workers in the textile industry. Their work had to be done very carefully; it also involved a great deal of heavy labour, and the handling of scissors could become painful at the end of a day's work.

Shearing had always been part of the process of production of cloth, but unlike fulling, it could not be done mechanically. As the fullers lost their prominence, the shearers became the most militant group in the seventeenth century. In Dutch cities their number was relatively large, because several of the earlier phases of production were carried out in the countryside or even outside the province of Holland. Dutch merchants increasingly imported unfinished cloth for shearing and finishing only. In their earliest protests, the shearers used the traditional form of the uitgang, obviously borrowed from the fullers. The Amsterdam shearers went to Haarlem in 1607. However, this protest proved to be unsuccessful. Eventually some of the shearers stayed in Haarlem, which had not been their intention. ${ }^{31}$ The first large-scale protest of the Leiden shearers in 1643 was also an uitgang. The shearers threatened to leave the city unless they were given higher wages. Some shearers did indeed leave the city, though they did not go further away than the surrounding countryside. Nevertheless, the government reacted immediately by writing letters to other cities urging them to prevent the shearers from Leiden obtaining work there. The city officials regarded the protest as a mutiny. The word uitgang no longer turns up in the sources. It seems that although the form was remembered, the specific word had already disappeared from the Dutch language. The last time it was used was in 1523. The Leiden protest also ended in failure, and those who had left the city soon returned.

${ }^{31}$ The Reformed Church was involved in this conflict because some of its members had participated in the protest. This involvement of church authorities, however, was exceptional. GA Haarlem, Kerkeraad Hervormde Gemeente resolutions of 21 September and 23 November 1608; GA Amsterdam Archief Hervormde Gemeente 3, resolutions of 1, 8 , 15 November 1607, 31 January, 11 September, 9 November 1608, and 26 March, 2 and 9 April 1609. 
Circumstances no longer favoured the uitgang as a weapon in any struggle between workers and employers. Dutch cities were in competition with each other much less than before; they no longer welcomed with open arms workers from elsewhere. Instead, since the Revolt against Spain, the cities had acquired an important share in the government of the country as a whole, through their seats in the States of Holland and the States General. The maintenance of public order and the acquiescence of workers was now one of their main concerns.

The same tendency had already led five years before to a decree issued by the States of Holland which aimed at regulating labour relations within the laken industry. The most important effect of this decree was that from now on workers had to show a statement in which their last employer declared that their employment had been terminated by mutual consent. Therefore, in theory, shearers who left their work as a result of conflict with their employers could never be employed again.

The employers also took measures. The manufacturers of woollen cloth within the province of Holland started to collaborate in 1637. They established an employers' organization, and from 1643 they held regular meetings to discuss all kinds of problems within the trade. For some time there also existed a national organization for the Dutch Republic as a whole. One of the aims of these two employers' organizations was to maintain labour acquiescence. This resulted in an agreement to refuse work to shearers who had left their last job in an "irregular" way. Employers kept a list of blackballed workers. Together with the decree of 1638, this made the uitgang useless as a strategy.

It is therefore not surprising that in the seventeenth century the most common form of conflict between workers and employers was the strike. The first documented strikes of the shearers overlapped with their unsuccessful attempts to revive the uitgang. By 1617 the shearers in the city of Alkmaar had already gone on strike to demand higher wages, "otherwise they would not go to work". ${ }^{32}$ In Haarlem in 1627 shearers were forbidden to conspire together (complotteren). ${ }^{33}$ Until around 1750 the strike remained the most powerful weapon available to the workers, and not only within the textile industry. The Dutch language was even enriched with a special word for it: uitscheiding. But before we consider the importance of uitscheiding we must analyze the social culture of the workers at the time of the Dutch Republic.

${ }^{32}$ L. Noordegraaf, "Textielnijverheid in Alkmaar 1500-1850", in Alkmaarse silhouetten. Uit de geschiedenis van Alkmaar en omgeving (Zwolle, 1982), pp. 39-65.

${ }^{33}$ GA Haarlem Stad, Resolutie Burgemeesters, 12 November 1627. 


\section{Court meetings in the seventeenth and eighteenth centuries}

In many trades workers met regularly outside working hours. Such meetings were an essential part of the social culture of the Dutch labouring classes. The shearers are again the best documented group. Between 1607 and 1710 in Amsterdam such meetings were explicitly forbidden no less than twelve times by the authorities. ${ }^{34}$ In Leiden these meetings are documented for the period between 1643 and $1744 .{ }^{35}$ Contemporaries confirmed that these meetings were "a traditional custom" of the shearers. In Amsterdam one of the bridges of the city was a regular meeting point. This bridge had since 1527 been designated by the city authorities as a place where workers who sought employment, and employers who sought workers, could gather. The bridge, however, not only served as an open-air employment exchange, but also as a place where workers could discuss their situation. ${ }^{36}$ In Leiden such meetings were usually held in inns. Sometimes the meetings were so crowded that the inns were too small and a number of people had to stay outside. The meetings were usually held on Sundays.

One objective was to settle disputes between workers and employers, and among workers themselves. The Dutch phrase used to describe such a meeting was court vergadering, which can best be translated as court meeting. The word court was probably borrowed from the French, where it meant a court of justice. Usually both parties in a conflict chose goede mannen, men who took it upon themselves to defend the cause of one party.

${ }^{34}$ Court meetings certainly took place in 1616 (van Dillen, Bronnen Amsterdam, II, no. 343), 1618 (Ibid., no. 444), 1626 (Ibid., no. 1057), 1631 (Ibid., no. 1382), 1638 (Ibid., III, no. 354), 1661 (Handvesten ofte privilegiën ende octroyen, mitsgaders willekeuren, cosuimen, ordonnantiën en handelingen der stad Amstelredam, 5 vols (Amsterdam, 17481778), III, pp. 1345, 1346 and 1348), 1682 (Ibid. , p. 1349), 1691 (Ibid., pp. 1348-1350), 1692 (Ibid., p. 1350), 1710 (Ibid., p. 1351). There are indications of meetings held in 1628 (Van Dillen, Bronnen Amsterdam, II, no. 1166), and 1633 (Ibid., III, no. 61). Cf. G. Kernkamp, "De 'droogscheerderssynode' ", in Geschiedkundige opstellen uitgegeven ter eere van H. C. Rogge (Leiden, 1893), p. 105. Shortly after 1700 masters complained about the court meetings of the shearers (GA Amsterdam RA 687, no. 85). In a sentence passed in 1724 court meetings are mentioned (GA Amsterdam RA 610, folios 219ff.). In 1737 there was "commotion" among the shearers (GA Amsterdam gilden 929), which possibly refers to court meetings. It is possible also that in 1765 court meetings were held (Handvesten Amsterdam, IV, p. 197; Nederlandse Jaarboeken 1765, p. 183). Van Dillen mentions a protest of shearers in 1744 (J. G. van Dillen, Van rijkdom en regenten. Handboek tot de economische en sociale geschiedenis van Nederland ('s-Gravenhage, 1970 ), p. 183), but he is probably confusing this with the strike of the cotton printers in that year.

${ }^{35}$ For a more extensive treatment see R. M. Dekker, "Arbeidsconflicten in de Leidse textielindustrie", in H. A. Diederiks et al., Armoede en sociale spanning. Sociaalhistorische studies over Leiden in de achttiende eeuw (Hilversum, 1985), pp. 69-87.

36 Van Dillen, Bronnen Amsterdam, I, no. 120. 
They were also called rechters (judges). In some cases each party had no less than six judges. The judges from both parties met separately and agreed upon an appropriate sentence. The sentence was read out during a general court meeting, and the journeymen could vote on it - a sentence could be approved by applause. In a sentence the guilty party was usually punished with a fine. The fine could be as high as three times the weekly income of a labourer. ${ }^{37}$ Not only the workers but also the employers went along with such procedures. This is all the more remarkable because court meetings were illegal. The city governments more than once forbade them. In Amsterdam in 1682, for instance, the Amsterdam authorities explicitly declared that shearers "should not punish each other". ${ }^{38}$ In 1710 it was again stated that they should not "punish each other in their usual way or levy fines". ${ }^{39}$ Conflicts in a trade should be dealt with by the responsible committees of neringen or guilds, or should be brought before the official law courts. Nevertheless, this form of informal justice was irrepressible. The fines were sometimes immediately used to buy drinks for all those in attendance, and in other cases they were donated to the city's poor fund..$^{40}$

The second objective of a court meeting could be to plan protests. Occasionally the sources yield information about such meetings. They were usually held outside cities, and, more importantly, just outside the territorial jurisdiction of the city officials. In Leiden in 1643, for instance, some 400 shearers met outside the city walls. One of the participants proposed "to stop working at some time". This proposal was accepted by most of the others present, and the shearers returned to the city and went on strike. ${ }^{41}$ During a court meeting outside the walls of Amsterdam in 1691 the shearers decided to go on strike. At the same time a deputy was sent to Leiden to enquire about wage levels there. ${ }^{42}$ When the meetings were held in an inn, the leaders would stand on a table to address the assembly. We shall return to the practice of court meetings later in this study.

A system of court meetings can be found among other groups of workers as well. There are indications of such in the case of the weavers of Amsterdam, who in 1657 had "a league and alliance". ${ }^{43}$ The same holds for the workers in the Amsterdam sugar refineries around the same time. ${ }^{44}$ The situation among the hatters of Amsterdam is better documented. It shows many resemblances with that of the shearers. Between 1657 and 1723 they

${ }^{37}$ Dekker, "Arbeidsconflicten", pp. 73-75.

38 Handvesten Amsterdam, III, p. 1349.

39 Handvesten Amsterdam, III, p. 1351.

40 Handvesten Amsterdam, IV, p. 197.

${ }^{41}$ LTN IV, no. 316; cf. no. 318.

${ }^{42}$ GA Amsterdam RA 337, folios 84v-88, 95, 102 and 128.

${ }^{43}$ Van Dillen, Bronnen Amsterdam, III, no. 1384.

44 Handvesten Amsterdam, IV, p. 1174. 
were repeatedly forbidden from having "illegal meetings" and from "punishing or imposing fines on their colleagues". ${ }^{45}$

\section{Solidarity: a matter of honour}

The system of informal justice, as well as the organizing of a protest, depended on solidarity between the workers. It was precisely this unity among the workers that puzzled the authorities. Therefore, when in Amsterdam in 1691 the leader of a group of striking shearers was arrested, he was asked, "what kind of order is there among the shearers?" The man explained that shearers used to make decisions during meetings. Those who disregarded these decisions were declared vuil (foul). Afterwards this stigma could only be removed by paying a daalder (thaler) or donating a pint of gin or brandy. Other sources show that this system was widespread. A shearer who was declared foul was also called schelm (scoundrel or blackguard), dief (thief) and oneerlijk (dishonest). The last of them was the most significant. A shearer who was declared foul had lost his honour; he was thrown out of the community of workers. On another occasion it was declared that "nobody would drink with a foul shearer". The importance of drinking was much more than that it was a form of recreation. Drinking together confirmed the solidarity of the shearers in a ritual way. For that reason, the stigma of foulness could only be removed by a drinking ritual at the expense of the worker who was thus "washed" and who thereby regained his honour. ${ }^{46}$ There was a strong preference for alcoholic beverages, beer, gin or brandy, but, as a shearer once declared, "even a drink of water" could be used during such a purification ceremony. ${ }^{47}$ Other groups of workers had the same type of rituals to enforce solidarity. Within the textile industry we find them among weavers, wool combers and cotton printers.

The loss of honour mirrored, like the court meetings, official justice. Criminals could be declared officially "dishonest", in addition to their receiving other punishment. Even without such an explicit sentence, criminals, especially thieves, were generally regarded as "dishonest". A worker who was expelled by his fellows was thus symbolically marginalized ${ }^{48}$ The

${ }^{45}$ Some industries are known to have had volatile labour relations, but they need to be studied in more detail. See, for example, for a study of the biscuit bakery in Wormer, C. Mol, Uit de geschiedenis van Wormer (Wormerveer, 1966), p. 106.

46 GA Amsterdam RA 337, folios 84v-88, 95, 102, 128 .

${ }^{47}$ Dekker, "Arbeidsconflicten", p. 74.

48 A. Blok, "Infame beroepen", Symposion, 3 (1981), pp. 104-139; A. Blok, "Eer en de fysieke persoon", Tijdschrift voor Sociale Geschiedenis, 18 (1980), pp. 211-231. See also the same author's Infamy (Cambridge, forthcoming). On the subject of honour see also Peter Burke, The Historical Anthropology of Early Modern Italy (Cambridge, 1987). 
ritual also resembled that of the charivari. During a charivari inhabitants of a village would punish a member of the community for breaking the rules of that community, for instance in the case of a man who refused to marry a girl whom he had made pregnant. Like the stigma of "foulness", the charivari had only temporal effect: as soon as the victim consented to obey the norms of the community, he was accepted again. Such charivari were found in the eastern provinces of the Dutch Republic and in the southern part, Brabant and Limburg. ${ }^{49}$ In Holland, even in the countryside, their occurrence was exceptional. In other words, the blackballing of workers was the urban counterpart of the rural charivari.

However threatening, in itself this ostracism was not enough to coerce all workers. Again and again some degree of verbal intimidation was necessary to put pressure on dissident workers. Conflicts could escalate during strikes, and therefore most of our sources relate to such contexts. For instance, non-strikers were threatened with violence if they continued to work in their workshops. Strikers used to march from one workshop to another to make sure that nobody was at work. During a strike in an Amsterdam shearers' workshop in 1724 one of the striking workers stood outside on the street, shouting insults at the non-strikers, and at his boss. Finally he challenged his boss, who was standing at the entrance to the workshop, to come outside "on the pavement of the magistracy" where "he would beat him up". ${ }^{50}$ It was an unwritten rule that such fights occurred not in the private space of a house or workshop, but in public.

A similar situation occurred in Leiden in 1648 , when a striker and a non-striker met in an inn. Their verbal assaults were continued outdoors, where the striker cut the face of the other with a knife. ${ }^{51}$ On a rather exceptional occasion, in Leiden in 1701, a group of striking weavers with drawn knives attacked a house where one of their colleagues was still working. ${ }^{52}$ City governments, like Gouda's in 1637 , more than once decreed during strikes that strikers should not "attack non-strikers with knives"..$^{53}$ Finally, during a strike of shearers in Amsterdam in 1700, two "foul" shearers were beaten black and blue and thrown into the water. They would have died had they not been saved by passing peasants; peasants obviously were not part of the city's community of workers, and could as neutral

49 See Gerard Rooijakkers and Tiny Romme (eds), Charivari in de Nederlanden. Rituele reacties op deviant gedrag (Amsterdam, 1989), for references to the international literature on this topic. See also Florence Koorn, "Illegitimiteit en eergevoel. Ongehuwde moeders in Twente in de achttiende eeuw", in Vrouwenlevens 1500-1800 (Jaarboek voor Vrouwengeschiedenis, vol. 8) (Nijmegen, 1987), pp. 74-99.

50 GA Amsterdam RA 382, folios 6v-9v.

${ }^{51}$ GA Leiden RA 3-M, folios 109-109v.

${ }^{52}$ Dekker, "Arbeidsconflicten", p. 76.

${ }^{53}$ GA Gouda Stad 326, folio 146; see also 316, folio $114 \mathrm{v}$. 
persons intervene. ${ }^{54}$ In general such violence was exceptional though. Strikers often acted with remarkable restraint, and the leaders could usually control their actions.

To declare someone foul was a decision with far-reaching consequences. It is therefore surprising that in the course of time this form of informal punishment was applied more often and for increasingly trivial offences. In Leiden in the eighteenth century reders complained that workmen were declared foul for trifling reasons. An occurrence in Amsterdam confirms this. In 1702 a shearer was declared foul because his wife had denounced a baker who kept pigs; the keeping of pigs was illegal under the city's laws. $\mathrm{He}$ was threatened with his whole workshop being declared foul if he continued to work. ${ }^{55}$ Maybe this informal mechanism of social control was used on a broader scale than one would at first sight expect. And maybe, as the power basis of workers became less solid in a time of economic decline, the distinction between charivari and blackballing became somewhat blurred.

\section{Strikes}

There are only a few strikes about which we have detailed information, but these can be profitably used to illustrate the position and behaviour of workers, employers and the authorities. One of the best documented strikes is that of the cotton printers in Amsterdam in $1744 .{ }^{56}$ Cotton printing was a booming industry from around 1700. In Amsterdam factories were built which, according to visitors, looked like palaces. The trade was not regulated by a guild or by the city government; indeed, it was completely unregulated. Some of the workshops were real factories with around a hundred workers. The owners were managers, the journeymen and apprentices were wage workers. There was a far-reaching division of labour, but hardly any degree of mechanization. The journeymen printers formed an elite. One of their tasks was to test by tasting with their tongues the acidity level of the vitriol used. Among the other groups of workers were women who painted the designs.

In 1729 a conflict between the masters and the journeymen took place. At that time there were at least thirty workshops with on average sixty journeymen. Wages were relatively high - around twenty guilders a week but the work was very unhealthy and the workshops were operating only during the summer months, starting on the first of May. The conflict was

${ }^{56}$ R. M. Dekker, “De staking van de Amsterdamse katoendrukkersknechts in 1744", Textielhistorische Bijdragen, 26 (1986), pp. 24-38. 
mainly about the wages paid for certain types of work, and about the number of apprentices employed. The apprentices were seen as low-paid substitutes for journeymen. After a short strike the masters and the journeymen made an agreement, which was recorded by a notary in the form of a petition and signed by twenty-seven masters and more than five hundred journeymen. Unter the terms of the agreement a limit of one apprentice to every seven journeymen was stipulated. The city government gave its official sanction to this agreement, which was seen as a victory for the journeymen. By the following year, however, some masters were petitioning the government to annul the agreement, but they had no success.

Nevertheless in the course of time the masters succeeded in weakening the terms of the agreement. By 1744 the dissatisfaction of the journeymen had become explosive. These were years of high food prices, which may have made them more sharply aware of their worsening situation. By then, in addition, there were masters who employed fifteen apprentices and not a single journeyman and some new types of work had been introduced without accompanying proper wage agreements. However, some of the older journeymen remembered the agreement of 1729 . On the second Sunday in May, one week after the beginning of the new work season, some twenty to thirty journeymen rented a back room in an inn. A list was made of all the types of work, varying from making handkerchiefs to "tissues with flowers", and with the corresponding wage rate for that work. This was printed and during a meeting all those in attendance took a copy. In the workshops where these wage rates were not in force the workmen were to go on strike. Messengers, chosen by means of dice, were dispatched to these shops. Much of the communication between the workers was written and a schoolmaster was asked to assist in this.

After a week a second meeting took place. This time six leaders were chosen. A journeyman who was afterwards interrogated by the bailiff, explained that these six men were chosen because they could read and write better than the others, and also because they "had better brains". They were called hoofden (heads) or gecommitteerden (representatives). This small committee had no chairman, and "all had an equal say" in its decisions in general meetings. The "heads" were in this respect no better than the common journeymen. The meeting was successful, and several masters accepted the proposed new working conditions; after a week there were only six foul shops out of a total of twenty.

The next week proved to be crucial. The six foul masters were stubborn, and refused to give in. The heads went to a lawyer and asked him if they could petition the authorities. The answer was that it was too late, because they had already gone on strike. The journeymen began to prepare themselves for a long fight, and it became imperative to help the strikers. At their last meeting workers shouted "We shall work for each other", and meas- 
ures to enable mutual assistance were quickly effected. The heads proposed that those who worked in "clean" workshops should contribute to a fund which would be used to provide grants to others, ensuring that workers and strikers had equal incomes. The condition, however, was that the strikers would pay back these grants once the strike was over. A bookkeeper was appointed, chosen like the "heads" because of his specific abilities: he was a former master who had declined to the status of journeyman. The gemene sosietijt or gemene beurs (common fund) existed for two weeks. In their favourite inn strikers were given money from the fund on two occasions; it was distributed by sprekers (speakers) from the six foul workshops. On the second of these occasions the journeymen decided to give the apprentices one guilder, so that "they too could stay alive". This was a magnanimous gesture, the more so because it was partly against the apprentices that the strike was directed.

Meanwhile the foul masters were under considerable pressure, not least from merchants wanting the cloth they had ordered. Three masters decided to petition the authorities. Their reaction was prompt. A decree outlawing the movement was immediately issued and on the night of 22 June six journeymen, including two of their leaders, were arrested. Though a riotous demonstration took place the next day, the action of the authorities effectively meant the end of the strike. The six were interrogated and received rather mild sentences varying from expulsion from the city for a period of two years to a few weeks in prison on a diet "of bread and water". One of them was released, after promising to return to work and to behave from now on "as a quiet and law-abiding citizen".

Not all strikes were as well organized and thoughtfully executed as that in Amsterdam in 1744. A far more complicated picture is offered by those in Leiden in 1700 and 1701 , two of the most turbulent years in the history of this city as far as labour relations are concerned. ${ }^{57}$ From July 1700 onwards a number of well-attended court meetings were held dealing with a variety of conflicts. In September the municipal authorities wanted to stop this, and a couple of shearers were arrested and expelled from the city. At the beginning of November, however, the shearers went on strike for higher wages. In December the city government issued a new regulation covering their wages, but the unrest did not subside. Riots were feared, and a watch was held during the night by the city's - professional - militia. The schutterij, or burgher militia, was also on the alert. In the middle of December a large court meeting of shearers took place which ended peacefully. A day afterwards at a second meeting it was decided to petition the mayors. They accepted the petition and promised to study the matter, but nothing more

${ }^{57}$ Dekker, "Arbeidsconflicten", pp. 73 and 75-76. See also C. W. Delforterie, "Iets over de stakingsonlusten van 1701 te Leiden", Rijnland (1964), pp. 104-109. 
came of that promise. Gradually feelings calmed down and only in the spring of the next year did strikes occur in three shearers' workshops.

The protests of the shearers fizzled out, but in the meantime the shearers had provided an example for the weavers of woollen cloth. On New Year's Day 1701 some 1000 weavers assembled outside the city walls to discuss the level of their wages. They subsequently made a formal request for higher wages. The city government immediately set up a committee to investigate the weavers' wages. A report was submitted in May but no action followed. The following day some 800 to 900 weavers assembled outside the city and refused to work until wages were increased. A meeting was arranged for later on the same day which was to be attended by all weavers of woollen cloth. Those absent were fined two stuivers. From now on every twentyfour hours meetings were organized. Each time new leaders were chosen, a measure designed to minimize the risk of reprisals by the authorities. More and more weavers participated in the meetings, and money was collected in order to set up a strike fund.

Initially the city government reacted with restraint, sending only two city beadles to forbid the meetings. This move produced no results and the magistrates ordered both the city militia and the burgher militia to stand watch during the night. The Grand Pensionary of Holland was requested to send a mounted company of soldiers from Den Haag. A subsequent meeting, attended by more than a thousand weavers, decided once again to march through the city and check on those still working. In the meantime the number of strikers' leaders had increased to sixteen. The day after, on 14 May, 1500 to 1600 weavers met twice and an official ban on such meetings was issued which made attendance punishable by a penalty of death by hanging. The following night four of the leaders were imprisoned. After this, peace gradually returned and by 21 May the mayors recorded that "all was quiet in the city". Although these movements were much larger than that of the Amsterdam cotton printers, the events followed the same pattern and also ended in failure.

The strikes described here are in many ways representative. Most strikes were well organized, and the participants usually acted with restraint. The strike leaders were usually somewhat older and more experienced than the others. The two leaders of the cotton printers arrested in 1744 were aged 43 and 47 . The average age of those shearers arrested in Leiden in 1700 was 36; the four weavers who were arrested a year later were on average 26. Four shearers arrested in Leiden in 1718 were on average 42, and more examples could be given. Most of these men were married or widowers, and they were certainly not angry young men.

We should also note that these protests were exclusively male affairs. Much work in the industry was done by women, for instance in spinning, but they did not develop a tradition of protest. This is all the more remarka- 
ble since women in the seventeenth and eighteenth centuries played an important role in riots over food prices and taxation, and also in political and religious riots. ${ }^{58}$ It is no surprise that only in the exceptional situation when a strike developed into a riot were women to be found among the participants. A strike of shearers in Leiden in 1718 ended with the plundering of the house of a manufacturer, and here a 55-year-old wool picker was arrested.$^{59}$ In Amsterdam in 1692 a 48 -year-old silk spinner who was married to a shearer was arrested. She had encouraged people to attack a shearers' workshop. ${ }^{60}$ Rather exceptional was a conflict about wages between two female silk spinners and their employer which developed into a riot and an attack on his house. Here again the pattern of conflict tended more towards the riot than the strike. ${ }^{61}$

There are more examples of violence used by strikers. In 1748 in Gouda hundreds of pipe makers broke the windows of the houses of their employers. The origin of this disturbance was the unemployment in the industry caused by a lack of clay. ${ }^{62}$ Another example is provided by a riot which occurred in Leiden in 1671. Orphans who were employed as spinners protested because "their masters kept them hungry", and they attacked the house of a director of the cloth nering. ${ }^{63}$ These cases were exceptional however, both because of their contexts and because of the use of violence. Excessive violence, such as house plundering, common enough during riots, was generally not a feature of labour disturbances.

The same holds true for another aspect of riots and revolts, their festive, charivari-like character. There are only a few traces of such demonstrative behaviour. The Amsterdam weavers marched through the city in 1657 "with drums beating". ${ }^{64}$ In 1672 carpenters and masons working for the city of Amsterdam marched through the city with a barrel as a drum and a leather apron as a banner, trying to prevent others from working. ${ }^{65} \mathrm{~A}$ similar riot had taken place in Haarlem a year before.$^{66}$ Another example is provided by the street brawl of Leiden fullers in 1619 mentioned before. However, in general protests were very much goal oriented and in this

${ }^{58}$ Rudolf M. Dekker, "Women in Revolt. Collective Protest and its Social Basis in Holland", Theory and Society, 16 (1987), pp. 337-362.

${ }^{59}$ Dekker, "Arbeidsconflicten", p. 80.

60 GA Amsterdam RA 338, folio 24v.

${ }^{61}$ GA Amsterdam RA $122 \mathrm{v}-126$.

${ }^{62}$ Nederlandsche Jaerboeken 1748, pp. 356-357.

${ }^{63}$ W. M. and A. van der Goes, Briefwisseling (1659-1673), ed. G. J. Gonnet, 2 vols (Amsterdam, 1899-1909), letter 247 (29 June 1671).

${ }^{64}$ Van Dillen, Bronnen Amsterdam, III, no. 1384.

${ }^{65}$ Kroniek Historisch Genootschap, 24 (1868), p. 458; L. J. van Beuningen van Helsdingen, "Eene werkstaking . . . in het jaar 1672", Amsterdamsch Jaarboekje voor 1904, p. 100.

${ }_{66}$ Van der Goes and Van der Goes, Briefwisseling, letter of 29 June 1671. 
respect the workers also acted with restraint, keeping their distance from charivari and riots.

\section{Demands}

Workers usually had specific goals, and wages were, already in the Middle Ages, a central issue. For instance, in 1637 the shearers of Gouda refused to work "unless they were paid 18 stuivers a day instead of the 14 or 15 stuivers which they received up until now". ${ }^{67}$ In other cases campaigns aimed to oppose the lowering of wages. Around the middle of the eighteenth century the Leiden combers protested against the fact that more and more was being deducted from their pay in order to contribute to the costs of cleaning the workshop. ${ }^{68}$ This example also shows how complicated the system of wage calculation was. Many workers worked on piece rates; in other instances the length of the day, or the type of work determined the level of wages. Frequently deductions were made by the masters for arriving late at work, damaging tools or producing bad work.

In some instances the demands of the workers were less clear. They could, for instance, relate to fringe benefits. In Amsterdam in 17362000 shipwrights marched through the city to protest against the withdrawal of their "drink money". And with success. ${ }^{69}$ The length of the working day could also be the cause of dispute, as was the case with the Amsterdam tailors in 1597; they successfully resisted employers' attempts to make them work all the daylight hours of the summer ${ }^{70}$ In 1627 in Haarlem shearers refused to work on Sundays. ${ }^{71}$

Conflicts often contained a degree of personal conflict. Again and again there were certain manufacturers who were for some reason particularly disliked by the workers; an example is the cloth manufacturer Van Gangel, whose house in Amsterdam was nearly ransacked in $1692 .{ }^{72}$ The conflicts among the shearers around 1700 in Leiden concentrated on the personality of David Marinier, a little-loved foreman. The manufacturer David Clignet was central to the conflicts in the same city from 1716 to 1718 . He was considered to be a difficult person, and both workers and guild masters came into conflict with him. Around 1730 a protest of shearers against the manufacturer Van Bommel was aggravated because he was "hated for both

${ }^{67}$ GA Gouda Stad, 326, folio 146; cf. 316, folio $114 \mathrm{v}$.

${ }^{68}$ Dekker, "Arbeidsconflicten", p. 79.

${ }^{69}$ Het ontroerd Holland, 3 vols (Harderwijk, 1749?), I, pp. 249-252.

${ }^{70}$ Handvesten Amsterdam, V, p. 1305; Timmer, Knechtsgilden, pp. 6-7.

${ }^{71}$ GA Haarlem Stad, Resolutie Burgemeesters, 12 November 1627.

72 GA Amsterdam RA 338, folios $22 \mathrm{v}-25 \mathrm{v}$, especially $24 \mathrm{v}-25$, and $49 \mathrm{v}-51$. 
his way of working and his character". Hendrik Snijders was a muchdisliked employer among the Leiden combers some years later ${ }^{73}$

"Foreign" workers could also be an object of scorn. In 1597 Amsterdam shipwrights refused to cooperate with colleagues who came from the nearby town of Edam..$^{74}$ In 1692 in Amsterdam it was explicitly stated that shearers had to accept workers from other cities as colleagues. ${ }^{75} \mathrm{~A}$ limitation on the number of apprentices was also a typical demand on the part of workers. The shearers in Amsterdam in 1700 demanded that the ratio of apprentices to masters should be no more than two to one. ${ }^{76}$

Especially virulent was the protest of the Leiden shearers between 1716 and 1718 against a new method of shearing which made the work less arduous. One of their actions was to petition the burgomasters, whom they asked to help uphold "their ancient freedom". ${ }^{77}$ This conflict was one not only about wages. The shearers obviously feared that this development would lead to a fall in the level of qualifications required to be a shearer, and therefore in their status in general.

\section{Informal organization}

The cotton printers who were arrested in Amsterdam in 1744 emphatically declared to the bailiff that they had not taken an oath, and that all decisions had been taken by voting. Furthermore, they insisted that "everything done was public", and that "everybody was allowed to know what they were doing". The journeymen had good reasons to make such statements. The bailiff was obviously trying to find out if they had established some form of secret organization. If this had been the case, their situation would have been much worse. Organizations of journeymen were forbidden throughout the Dutch Republic, with few exceptions. Emilia Timmer's study of the subject looked at the situation in twenty-two cities throughout the Republic. ${ }^{78}$ The only form of organization permitted, and that only after the beginning of the eighteenth century, was the "box" (beurs or bos) for journeymen. Members of a box contributed a small sum every week in return for the right to financial assistance in case of illness or death. Each city usually had only two or three such boxes. In Amsterdam for instance,

${ }^{73}$ Dekker, "Arbeidsconflicten", pp. 81-82.

${ }^{74}$ GA Amsterdam Notarieel Archief 78, folios 171-172.

${ }^{75}$ Handvesten Amsterdam, III. For a study of the problems in 1717 see N. W. Posthumus (ed.), Bescheiden betreffende de provinciale organisatie der Hollandsche lakenbereiders (Amsterdam, 1917), p. 155.

${ }^{76}$ GA Amsterdam RA 687, no. 85.

7 LTN VI, no. 217.

78 Timmer, Knechtsgilden. 
there were no more than two, one for linen weavers, the other for shipwrights. Such organizations never developed into workers' associations. Furthermore, their regulations were usually confirmed by local authorities, who thus controlled them.

Lacking official organizations, the only social basis for protest was provided by informal networks. Workers within the same branch of industry usually had a strong sense of community, especially those who worked together in relatively large workshops, like the shearers or the hatters. Not only did they work together, but they often lived in the same neighbourhoods, drank in the same inns, and shared the same pastimes. The traditions of the court meeting and the strike could obviously survive very well without the need for formal associations, statutes, or official membership.

Nevertheless, the absence of permanent organizations made itself felt again and again. It was especially difficult to organize a strike without having a strike fund. Occasionally strikers did try to form one, like the Leiden shearers in 1700 or the Amsterdam cotton printers in 1744. This happened more often, as in 1710 in Amsterdam, where the shearers were forbidden "to collect money from their colleagues". ${ }^{79}$ Stocking weavers in Leiden in 1724 made the following agreement: weavers who were paid fair wages not only offered to pay the daily expenses of the strikers, but also a sum to allow them to travel to other cities. Paying colleagues to leave a city to put pressure on manufacturers during a strike resembled the "tramping system" in England, and the former uitgang in Holland. ${ }^{80}$ Such forms of aid were, with variations, also found in Germany and France. In Holland this is the only case of "travel money" being mentioned, and it is probably no coincidence that this group of weavers was entirely made up of Frenchmen. What was more, the stocking weavers were, among other things, accused of illegally trying to form a guild; this is the only time that interrogations led to a formal accusation of this particular offence. ${ }^{81}$

Given the lack of organization, it is surprising that workers from different cities nevertheless had contacts with each other. There is evidence of this relating to the fullers around $1500,{ }^{82}$ and later the shearers. In $1700 \mathrm{Am}$ sterdam shearers sent two "judges" to a court meeting in Leiden. ${ }^{83}$ In one case contact was maintained through letters. A letter from 1741 has survived in which the Amsterdam shearers asked those of Leiden "to follow the same line, or else our loyal fraternity will come to an end". ${ }^{84}$ According

is Handvesten Amsterdam, III, p. 1349.

${ }^{80}$ R. A. Leeson, Travelling Brothers. The Six Centuries' Road from Craft Fellowship to Trade Unionism (London, 1979), p. 153.

${ }^{81}$ Dekker, "Arbeidsconflicten", p. 77.

82 GA Haarlem Stad, Dictum Hof van Holland, 31 March 1500.

${ }^{83}$ Dekker,"Arbeidsconflicten”, p. 80. 
to one source, the Amsterdam cotton printers wrote letters to colleagues in other cities, probably with a similar request. The fact that more than once shearers went on strike in several cities at the same moment suggests a degree of deliberate cooperation. Between 1636 and 1639 a wave of strikes took place in Haarlem, Hoorn, Gouda and Rotterdam. ${ }^{85}$ It was this wave which led the employers to work together, and the States of Holland to issue a decree against labour unrest. In 1724 there was another instance of simultaneous action when shearers went on strike in both Leiden and Amsterdam ${ }^{86}$ However, it is obvious that workers, who could not even establish a permanent organization within one city, were even less able to maintain permanent contact at a provincial or national level.

\section{Sailors}

Sailors were by far the largest group of wage labourers. The biggest employers were the East India and West Indies Companies (WIC and VOC). Their ships usually had around two hundred men, and sometimes twice as many far larger numbers than could be found in workplaces ashore. Another large group of sailors was in service of the navy, while others worked on smaller merchant ships, sailing to southern and northern Europe. Finally there was a large fishing fleet made up of still smaller ships, partly based in coastal villages.

Sailors often had some share in the spoils of war, in the case of the navy, or in the catch, in the case of fishermen; in the case of the VOC and WIC they were allowed to import a limited amount of foreign goods for themselves. But nevertheless they were first and foremost wage earners. They signed a contract and were paid on a monthly basis. It is therefore not surprising that they should resort to strikes during conflicts with employers. In the fishing village of Scheveningen in 1764 the fishermen refused to set sail in protest against a diminution in their share of the catch. During Easter, they met together at the church. Their leaders proposed, and it was agreed, that they should prevent the boats from sailing by removing the rudders. They also appealed to the village sheriff, because fishing was, like many industries, regulated by the government. Their appeal was unsuccessful, and finally the leaders were sentenced to four years' imprisonment and banished for ten years. ${ }^{87}$ Such conflicts occurred more often. In the fishing

\footnotetext{
84 Idem.

${ }^{85}$ LTN IV, 391 note 1; GA Gouda Stad 326, folio 146; GA Rotterdam Stad 496, p. 211 (17 November 1637); Posthumus, Bescheiden lakenbereiders, no. 7 (Haarlem); Ibid., nos 5,6 and 8 (Hoorn).

${ }^{86}$ GA Amsterdam RA 382, folios 6v-9v.

${ }^{87}$ GA Den Haag RA 109 , folios $48 v-50$.
} 
town of Brielle in the seventeenth century fishermen again and again came into conflict with the shipowners, sometimes threatening to throw them into the water. ${ }^{88}$

The sailors employed by the navy, the VOC and the WIC could be even less friendly when they were in dispute with their employers. Theirs was unskilled work and so replacements could easily be found. Secondly, since they were usually paid afterwards, it was hardly practicable to go on strike before or during a voyage. Nevertheless, sailors occasionally refused to work during a voyage. The reasons could involve complaints about the food, or demands for extra pay for a certain kind of work. This was always regarded as a mutiny, and heavily punished, as a recent study of fifteen mutinies aboard VOC ships in the seventeenth and eighteenth centuries shows. ${ }^{89}$

Ashore, in the harbour towns of Holland, some protests turned into real revolts. In Amsterdam in 1629 sailors attacked the head office of the East India Company in order to appropriate a larger part of the booty taken from a captured Spanish silver fleet. The riot made a great impression at the time, and the Dutch playwright Vondel wrote a poem about it. ${ }^{90}$ The revolt ended in a clash between soldiers and sailors. In 1635 another riot by sailors did not develop into a revolt. ${ }^{91}$ But one in 1652 , when some sailors returning from the East organized a demonstration before the head offices of the VOC, did. One leader declared after having being arrested "that they only wanted to receive their pay". Indeed, the VOC, the WIC, as well as the navy, were notorious for being far behind in paying their sailors. Afterwards, two leaders were hanged. The hangings attracted a large crowd, and panic broke out. Soldiers tried to restore order but the result was that there were several dead and wounded.$^{92}$ Much less violent, but equally interesting, is a case in 1678. Around one hundred women, armed with sticks and other weapons, demonstrated in front of a house where sailors enlisted for the Danish fleet (Denmark was an ally at that time). Their husbands

${ }^{88}$ See, for instance, GA Brielle Stad, Keuren en ordonnantiën 1596-1644, folio 145 (1 May 1623).

${ }^{89}$ J. R. Bruijn and E. S. van Eyck van Heslinga, Muiterij. Oproer en berechting op schepen van de VOC (Haarlem, 1980).

90 J. Wagenaar, Amsterdam, 4 vols (Amsterdam and Harlingen, 1760-1788), I, p. 507; GA Amsterdam RA 298, folios 48v-53; 575, folio 153v; Joost van den Vondel, De volledige werken, H. C. Diferee (ed.), 2 vols (Amsterdam, s.a.), I, pp. 275-276.

${ }_{91}$ GA Amsterdam Stad, Resoluties Vroedschap 24 September 1635 (cf. 15 April 1636); Kroniek van het Historisch Genootschap (1867), pp. 1, 30 and 87.

92 J. Wagenaar, Amsterdam, I, p. 585; Hollandsche Mercurius (1652), pp. 91-93; GA Amsterdam RA 309, folios 90-98; 581, folios 159-161v, Keurboek M, folios 165v-167v; Amsterdamsche beroerte voor-gevallen door de moetwil van eenige matrosen (Amsterdam, 1652); Oprechte beschrijving van al hetgeen tot Amsterdam is voorgevallen (Amsterdam, 1652). 
were also sailors, and still at sea. The women were protesting against the recruitment of new sailors while their husbands were still unpaid. The city authorities regarded their demands as well grounded, and although their behaviour was technically rebellious the recruiting officer was asked to ensure the prompt payment of monies due to them. ${ }^{93}$ Earlier, in 1640, women whose husbands had been captured by the Spanish came from all over the country to Den Haag to press for an exchange of prisoners. ${ }^{94}$

Other harbour cities, like Enkhuizen, in 1672 and $1673,{ }^{95}$ Hoorn, in $1623,{ }^{96}$ and Rotterdam, in $1637,{ }^{97}$ had their share of such rebellions too, and they all displayed the same pattern. The last series of riots by sailors took place in Amsterdam, between 1737 and $1743 . .^{98}$

The differences between the conflicts of the sailors and those of workers in trades ashore are clear. There was no trace of a permanent organization, nor even of an attempt to establish one. Their protests were much more spontaneous, and ended rather sooner in riot. The authorities feared sailors much more than onshore workers, even the shearers. They reacted more violently to the threat of unrest among sailors, and when sailors were arrested they tended to be much more severely punished.

\section{Navvies}

There was another group with a unique identity and social culture: the navvies, the labourers who dug the dikes and canals. They had a reputation for being rude and prone to rebellion. In his treatise on impoldering, written around 1578, Andries Vierlingh called them "a bunch of villains and rogues [. . .] who were easily incited to riot [. . . ] to use violence to get more money". Apart from all the technical problems associated with impoldering, it was, according to Vierlingh, of great importance to turn these

${ }^{93}$ GA Amsterdam Stad, Scheltema III Afd. IV, 41 (stadsmissivenboek 1678-1681, folio 6v).

${ }_{94}$ Resoluties van de Staten van Holland (printed); resolutie of 19 July 1640.

$95 \mathrm{G}$. Brandt and S. Centen, Geschiedenis van Enkhuizen (Hoorn, 1745), Vervolg, p. 349.

96 A. van der Capellen, Gedenkschriften 1621-1654, ed. R. J. van der Capellen, 2 vols (Utrecht, 1777-1778), I, p. 164.

97 ARA Hof van Holland Resolutie Gecommitteerde Raden 25 June 1637; Resoluties van de Staten van Holland (printed), resoluties of 15 April 1636, and 13 and 14 October 1637.

${ }_{98}$ J. Wagenaar, Amsterdam, IV, pp. 65 and 75; ARA 1st Afd., coll. Rademacher 237, letter of 22 August 1738; Het ontroerd Holland, I, pp. 252, 253, 295 and 296. GA Amsterdam Keurboek S, folios 239v and 250; RA 613, folios 105-106v; Het dagboek van Jacob Bicker Raye, eds F. Beijerinck and M. G. de Boer (Amsterdam, s.a.), pp. 56 and 74. 
"wolves into sheep". ${ }^{99}$ In fact, however, the archives reveal only a few instances of such riots. An early example is to be found in Leiden in 1611. A man, originally a wool spinner but now a navvy working on a project in the town, had borrowed a drum from his neighbour and called a meeting of his colleagues. His purpose was to encourage them "to stop working [. . .] in order to press for better wages". After the meeting the navvies marched with the drum and their spades back to the city. Upon their arrival the gates of the city were closed, and the leader was caught, paraded through the city and banished for twelve years. ${ }^{100}$ No evidence has been found that similar protests occurred during the period 1650-1750. Work on dikes and impoldering had virtually stopped, largely because of economic reasons.

The next instance of such protests dates from more than a century later. In 1772 on the island of Overflakkee around a hundred navvies working on dikes decided to press for higher wages. They threw wagons upside down, destroyed their spades and demanded free drinks. This group forced some two hundred other men to go on strike too. After a few days twenty-four soldiers succeeded in restoring order. ${ }^{101}$ In 1776 in another part of the countryside a similar event took place. ${ }^{102}$ In both cases the navvies were mainly from Germany. Both these were also similar to protests which took place during the first half of the nineteenth century, for instance in 1823 during the construction of the Noordhollands canal, the impoldering of the Zuidplas in 1840, the Haarlemmermeer in 1841, and near Kolhorn in 1844, and the construction of the railroads. ${ }^{103}$ The continuity between the eighteenth and nineteenth centuries is remarkable. However, these events can hardly be compared with industrial protests. The navvies formed a socially-

\footnotetext{
99 Andries Vierlingh, Tractaet van dyckagie, ed. J. de Hullu and A. G. Verhoeven ('s-Gravenhage, 1920), p. 100.

${ }^{100}$ GA Leiden RA 3-6, folio 282 (sentence passed on 17 June 1611).

101 ARA Hof van Holland 5480 (26). For such protests in nearby Zeeland see Nederlandsche Jaarboeken 1773, p. 795. See also G. J. Lepoeter, "De bedijking van de Reigersbergerpolder in 1773", Historisch Jaarboek voor Zuid-en Noord-Beveland, 9 (1983), pp. 15-34. An earlier protest in Holland took place near Hardinxveld in 1737 although it remains unclear whether the riot was caused by discontent over wages. ARA Staten van Holland, Resoluties Gecommitteerde Raden of 9 September 1737.

${ }^{102}$ W. Sonneveld, "Van een staking in 1776", Nederlandse Historiën, 7 (1973), pp. 277-280.

${ }^{103}$ J. Sprenger and V. Vrooland, "Dit zijn mijn beren". Een onderzoek naar de arbeidsverhoudingen bij de aanleg van het Noordhollands kanaal (Amsterdam, 1976); I. J. Brugmans, Paardenkracht en mensenmacht. Sociaal-economische geschiedenis van Nederland 1795-1940 ('s-Gravenhage, 1969), p. 194; cf. Alex Geelhoed, "Spades are Trumps. Strikes of Navvies at the Construction of the Utrecht-Arnhem Railway", in Lex Heerma van Voss and Herman Diederiks (eds), Industrial Conflict (Amsterdam, 1988), pp. 147-165; GA Haarlem, resoluties burgemeester en wethouders van Houtrijk en Polanen, 14 June 1841; Herman Vries, unpublished paper, and interview in the Schager Courant of 6 May 1982.
} 
isolated group of migrant workers who had their own social culture. Such protests about wages, which easily developed into riots, were part of that particular culture. It has recently been suggested by historians that these protests formed a trait d'union between the ancien régime and the modern period, but that is very unlikely. The navvies stood too much apart from Dutch society as a whole.

\section{The employers}

In those branches of industry which were organized into guilds or neringen, the employers had a permanent organization. Although they were obviously competitors, in respect of labour relations they had a common interest. This unity gave them a considerable advantage. They could, for instance, far more easily than the workers petition the local government.

The master hatters in Amsterdam can serve as an example of cooperation at a local level. Their guild had in 1633 received official permission to keep a register of journeymen who disobeyed their rules, and to blackball them. The central issue at that time was that the journeymen demanded that masters be allowed to employ only one apprentice instead of two. ${ }^{104}$ In 1638 eight master hatters in Amsterdam made an agreement before a notary. They decided that each would employ two apprentices, knowing that the journeymen had made a pact to work only for masters who employed one. Journeymen who went on strike would be blackballed. They also agreed that they would "borrow" journeymen from each other so that every workshop would have an equal number. They would act "as though they were one body", and those failing to keep to this promise were required to pay a fine to the poor chest of the Reformed Church. This formal organization thus mirrored in many respects the informal organization of the journeymen hatters. Nevertheless, it did not develop into a permanent organization of master hatters. ${ }^{105}$

In the cloth industry the employers were more successful. In 1616 they came from all the country to Den Haag to petition the States General to limit the level of cloth imports. From then on they continued to hold informal meetings. Within the province of Holland cooperation became somewhat closer after 1637 , and became formalized in 1643 . Every two years meetings were held. One of the aims of these meetings was to identify rebellious workers and ensure that they were not employed in the future; another was to equalize the level of wages throughout the province, and in 
general to promote the interests of the employers in relations with government. ${ }^{106}$

However, employers were not always united against the workers. In 1708 the master hatters in Amsterdam were very much divided among themselves. ${ }^{107}$ During a demonstration through Amsterdam organized by shearers in 1691, a master shearer stood aside and urged them on. "Be staunch", he shouted, "Do not go to work." To other masters who looked on at the proceedings he shouted insults $k r u k$ (duffer) and schelm (scoundrel). Finally he was arrested along with some of the demonstrating journeymen. In this case maybe small masters had certain interests in common with the journeymen; for instance, both worked for the big manufacturers, the reders. ${ }^{108}$

\section{The authorities}

The authorities were often involved in conflicts, if only because in many trades labour relations were regulated from above. Workers could therefore call upon the authorities to intervene on their behalf. This could be done in a disorderly way, as it was in 1691 in Amsterdam. The 47-year-old leader of a strike of shearers shouted during a march through the city which had ended at the town hall: "Men, come, follow me. I'll show you the burgomasters' chamber." 109 The burgomasters were not charmed by this approach, and the man was afterwards arrested.

In some cases workers petitioned the government. Petitioning, in general, however, was risky. Petitions were regarded with some ambivalence by the authorities. If they did not like the petition, it could be declared "unlawful". And obviously, if a whole group of workers petitioned the government, they had in some way "combined", and that was forbidden. An example of a general petition can be found in Leiden in 1718. Four shearers asked "in the name of all the shearers" for the "paternal support" of the burgomasters against the masters, who wanted to introduce new shearing techniques. ${ }^{110}$ In 1788 the shearers petitioned the city government to prevent manufacturers from leaving the city and setting up elsewhere. ${ }^{111}$ Individuals could also petition the government. In 1770 two shearers from

106 N. W. Posthumus (ed.), De nationale organisatie der lakenkoopers tijdens de Republiek (Utrecht, 1927); Posthumus, Bescheiden lakenbereiders; Kernkamp, "De 'droogscheerderssynode' ", pp. 85-132.

107 Handvesten Amsterdam, III, p. 1266.

108 GA Amsterdam RA 388, folios 49v ff.

109 GA Amsterdam RA 337, folio 102.

110 LTN VI, p. 217.

11 LTN VI, no. 339. 
Leiden dared to draw attention to how miserable their condition was. One wrote, "We request and beseech our true government (that we might enjoy) some solace because the children languish in their cradle, they call for bread and their parents sigh because as a result of unemployment they cannot give it." The other reminded the city officials of an ordinance dating from 1531 against the setting up of industries outside cities. In itself it seems surprising that workers knew of the existence of such ordinances, although in this case it did not help them very much. ${ }^{112}$

There were other ways in which the authorities could be involved in labour disputes. Of the smaller conflicts between masters and workers many were fought out before local courts of justice. In Amsterdam the schepenbank even had a special commission to deal with this type of conflict. Often these conflicts were about wages, the quality of the product or, in some cases, theft by workmen. These smaller-scale conflicts have not yet been adequately studied by historians however.

Many disputes indirectly concerned local government, as was the case with the court meetings of the Amsterdam shearers in 1607, 1616 and 1618. Such disputes were not necessarily unsuccessful. Although the meetings were suppressed, after the struggles of 1616 the burgomasters urged manufacturers "to raise the level of wages, which are really meagre". ${ }^{113}$

The authorities were, however, primarily responsible for maintaining public order. Strikes and court meetings, let alone disorderly marches or demonstrations, were therefore forbidden. During the seventeenth century the laws against court meetings became more and more severe. In Amsterdam in 1607 the punishment was a fine of three guilders, in 1618 ten guilders, and in 1691 the death penalty was introduced. In Leiden a similar pattern of change took place. The use of violence by strikers had already been forbidden in $1643 .{ }^{114}$ In 1718 the States of Holland, at the request of the city of Leiden, issued an ordinance against all forms of rebellious behaviour by shearers, threatening them with the death penalty for noncompliance. ${ }^{115}$ In Leiden the first sentences were pronounced during the period 1643 to 1648 . This was a turbulent time, and there were a number of small disputes, mostly poorly documented. Some shearers were condemned to be banished from the province of Holland for several years, others were imprisoned for three weeks and released on the condition that they offered a guarantee of good behaviour in the future. ${ }^{116}$ During conflicts

${ }^{112}$ LTN VI, no. 340.

${ }^{113}$ Van Dillen, Bronnen Amsterdam, II, no. 343.

${ }^{114}$ LTN II, no. 318 (26 June 1643).

${ }^{115}$ Europische Mercurius 1718, pp. 196-197.

${ }^{116}$ GA Leiden RA 3-13 folio 204, sentence passed on 27 August 1643, folios 211-212; LTN IV, no. 319 , p. 393 note 1 (1642 instead of 1643 ), no. 329 , p. 424 note 1; GA Leiden RA 3-14, folio 8v, sentence passed on 3 May 1644; LTN IV, no. 338; GA Leiden RA 
in Leiden in 1700 and 1701 several shearers and weavers were sentenced to be whipped and banished. Discontent in 1718 saw recourse to such sentences again. In Amsterdam prior to 1691 there is no archival evidence that such sentences were ever handed out. In that year, however, a shearer who had led a protest was sentenced to be whipped. ${ }^{117}$ The next year in a similar case a shearer was sentenced to one year in jail and to be banished from the city for a subsequent period of two years, while two other men were condemned to three months imprisonment and banishment. ${ }^{118}$ After a strike in 1700 two shearers, condemned to three years in the workhouse, were later banished. In this case it is clear that the severity of their sentence owes something to their having assaulted a colleague. The cotton printers who were arrested after a strike in 1744 were sentenced to short terms of imprisonment varying from one to three weeks. The death penalty, although in Leiden in some cases demanded by the bailiff, was never used. ${ }^{119}$ Still, there was obviously a more severe approach being taken by the authorities from the end of the seventeenth century onwards. The tendency towards greater severity was similar to the development between the fourteenth and the sixteenth centuries. What happened in the seventeenth and eighteenth centuries, however, coincides with a general trend in changing judicial practice. ${ }^{120}$ Compared with sentences for other crimes, workers were treated rather leniently. Seamen, as we have seen before, were an exception to this rule. They were regarded with suspicion, and therefore received much more severe sentences, sometimes even the death penalty. In the course of the eighteenth century a more humane approach seems to have prevailed, even towards sailors.

\section{Protest and economic conditions}

The year 1672 spelled disaster for the Dutch Republic. The country was at war with both England and France, and the economy collapsed down. The wages of the carpenters and masons in the service of the city of Amsterdam fell and they reacted by marching through the city. One of the burgomasters

3-14 folios $57 \mathrm{v}$, sentence passed on 3 July 1645 ; folio 41 , sentence passed on 17 April 1648; RA 4-M, folios 24-28v, 31v-56v, 70-70v, 98-99 and 109-109v. See also H. M. van den Heuvel, De criminele vonnisboeken van Leiden 1533-1811 (Leiden, 1977-1978).

${ }_{117}$ GA Amsterdam RA 337, folios 84v-88, 95, 102 and 128.

118 GA Amsterdam RA 338, folios 22v-25v and 49v-51; RA 597, folios 76v-77v.

119 Several historians have claimed that strikers in the Dutch Republic occasionally did receive the death penalty. In this they are repeating a remark by $\mathrm{N}$. W. Posthumus, who mistook a sentence demanded for a sentence pronounced.

${ }^{120}$ Pieter Spierenburg, The Spectacle of Suffering. Executions and the Evolution of Repression: from a Preindustrial Metropolis to the European Experience (Cambridge, 1984). 
addressed them. He told them, "everybody has to cut down a bit because of these hard times. When things are better your wages will be raised." The workers asked "Do you promise us better wages in better times?" Thereupon the burgomaster confirmed his promise, and they shook hands on this informal agreement. ${ }^{121}$

In this case the relationship between protest and economic conditions is obvious. It is much more difficult to establish a more general relationship between labour protest and economic change. ${ }^{122}$ First of all there were two discernible patterns at this time, one affecting commerce and banking, the other industry and the standard of living. In times of bad harvests and high prices, commerce and banking could flourish, and vice versa. The second pattern is important here. One could expect strikes either during a period of economic growth, because workers were eager to profit from this, or during a period of economic decline, because workers wanted to protest against cuts in wages. Bad harvests and high food prices could be followed by large-scale unemployment and this type of economic crisis was typical of the ancien régime.

There are only a few instances where protests occurred during a period of economic improvement. Amsterdam shipwrights were, especially in the first half of the seventeenth century, in a comfortable position. Without having to resort to large-scale protests they reduced the length of their working day from fourteen hours to twelve - a relatively short working day. ${ }^{123}$ When the fleet from the Baltic returned in the autumn, the Amsterdam corn porters negotiated a level of wages that was three times the normal rate. ${ }^{124}$ And in 1628 , when in the next spring the same fleet was preparing to depart, the shearers went on strike right at the moment when the manufacturers were trying to export as much woollen cloth as possible. ${ }^{125} \mathrm{~A}$ relatively late example of strikes being used as a weapon during a time of industrial growth within a trade can be found in Amsterdam in 1729 in the strikes among the cotton printers.

The Republic suffered less from food shortages than most other countries in Europe. Nevertheless, there were years of dearth, if not hunger. The most severe were those of $1623,1630,1637,1699,1709,1740$ and 17721773. There were economic crises in 1652-1653, 1672-1673, 1720 and 1763.

${ }^{121}$ Kroniek Historisch Genootschap, 24 (1868), p. 458; Van Beuningen van Helsdingen, "Eene werkstaking . . . in het jaar 1672", p. 100.

"22 See here Claudia Taken, "Kollektief protest in Amsterdam in de 18e en 19e eeuw" (Ph.D., University of Amsterdam); A. T. van Deursen, Het kopergeld van de Gouden Eeuw, 4 vols (Assen, 1978-1980), I, pp. 20-23, and N. W. Posthumus, De geschiedenis van de Leidse Lakenindustrie, 3 vols (Den Haag, 1908-1939), II, p. 1170.

${ }^{123}$ Leonie van Nierop, "Bijdragen tot de geschiedenis van de Amsterdamse scheepsbouw", Jaarboek Amstelodamum, 48 (1933), p. 38.

124 Van Dillen, Bronnen Amsterdam, III, no. 282 (1640).

125 Van Dillen, Rijkdom, p. 297. 
Some of these years coincided with protests, by shearers in various cities in 1637 and 1638 for example, while the disturbances in Amsterdam in 1700 and 1701 by shearers and weavers may also have been the result of the crisis of 1699 . The protest by the cotton printers of Amsterdam in 1744, and the recurrent riots of sailors in the early forties can be seen against the background of the crisis of 1740 . Nevertheless, other reactions were more directly linked with these food crises - the tax revolts of 1624 , the food riots in various cities in $1630,1698-1699,1709$ and in $1740-1741$ for example. ${ }^{126}$ Some strikes occurred in times of acute political crisis, such as the various protests in Leiden in 1748, at the distilleries in Schiedam ${ }^{127}$ and the pipe industry in Gouda in the same year.

The relationship between protest and long-term economic development is difficult to demonstrate. After the middle of the seventeenth century a decline set in in many Dutch industries. Between 1671 and 1750 textile production in Leiden fell by fifty per cent, and thereafter decline continued even more rapidly. The same development was characteristic of other, though not all, trades. From the beginning of the seventeenth century until around 1750 protests among workers showed a remarkable degree of continuity. After the middle of the eighteenth century their number dwindled. It seems that at that moment decline had reached a critical point. The labouring classes had disintegrated, and many workers, particularly those who were the most enterprising, had left the city; the most enterprising were probably also those most likely, under other circumstances, to have been willing to participate in labour protests. There is evidence of economic and urban decline in other cities too. At the end of the eighteenth century many houses were empty, and sometimes whole streets were demolished. In short, Holland no longer offered good opportunities for labour protest.

\section{Labour culture and political culture}

Political conflict was a regular occurrence in the Dutch Republic. Major political crises took place in $1617-1619,1653,1672,1747-1749$, and 1784 1787. There were also many local political conflicts, confined to one town or one province. These conflicts usually split society from top to bottom. The middle and lower classes were no less involved than the upper classes. Middle-class political protest could involve the guilds and, more often, the schutterijen (burgher militias) developing into alternative centres of power. During the crisis of 1747-1749, for instance, in many towns schutters held meetings. They refused to obey their officers, who represented the patri-

${ }^{126}$ Dekker, Holland in beroering, pp. 23-38.

127 GA Schiedam Stad 270 (11 December 1748). 
ciate and the city governments. Instead they drew up lists of political demands, and petitioned the government. These demands usually included the right of the common schutters to choose their own officers, thereby establishing the schutterij as an independent institution, and a rival centre of power to the city governments. The schutters were recruited from the middle classes, but, particularly in small towns, also from artisans.

Besides the traditional guilds and schutterij informal associations could also develop. In 1748 there were regular meetings of Haarlem weavers, twiners and the like. They even had a regular meeting place where they drew up petitions. The participants chose four delegates to represent them. ${ }^{128}$ During a revolt in the same city two years later, the common schutters elected a committee to bring their grievances to the attention of the authorities in Den Haag. The committee consisted of eight workers, among them two weavers, a twiner journeyman, and a tailor - precisely the sort of people who might otherwise be involved in labour disputes. ${ }^{129}$

In Leiden in 1749, the popular movement was even better organized than in Haarlem. ${ }^{130}$ All sixty-four neighbourhoods had chosen "speakers", while the leadership was entrusted to a group of ten "upper speakers". The resemblance to the court meetings and the organization of strikes is obvious. In 1749 there was in Leiden even a direct connection between politics and the labour movement in the form of a "political strike". Workers from all trades went on strike to press for reform of the city government. ${ }^{131}$ This strike is unfortunately badly documented, but it probably had no lasting results. Informal political clubs of workers also existed in the $1780 \mathrm{~s}$, during the Patriotic Revolution. ${ }^{132}$

The holding of meetings and the election of leaders were essential elements of the political culture of the middle and working classes. The customs associated with the court meeting were, in fact, transposed to the level of politics. Historians have always believed that in Europe political culture, including the concept of majority rule and voting procedures, was

${ }^{128}$ J. A. F. de Jongste, Onrust aan het Spaarne. Haarlem in de jaren 1747-1751 (n.p., 1984), pp. 246-249.

129 R. M. Dekker (ed.), Oproeren in Holland gezien door tijdgenoten (Assen, 1979), pp. 129-173.

${ }_{130}$ Maarten Roy Prak, Gezeten burgers. De elite in een Hollandse stad, Leiden 1700-1780 (n.p., 1985), pp. 91-99, "Burgers in beweging. Een politieke analyse van de Leidse onlusten van 1748", forthcoming in a book edited by J. Aalbers and L. Kooijmans. See also Maarten Roy Prak, "Civil disturbances and urban middle class in the Dutch Republic", Tijdschrift voor Sociale Geschiedenis, 15 (1989), pp. 165-173.

131 Dekker, “Arbeidsconflicten", p. 79.

${ }^{132}$ Rudolf M. Dekker, "Revolutionaire en contra-revolutionaire vrouwen in Nederland, 1780-1800", Tijdschrift voor Geschiedenis, 102 (1989), pp. 545-564. The most important local study of popular politics in this period is Wayne P. Te Brake, Regents and Rebels. The Revolutionary World of an Eighteenth-Century Dutch City (Oxford, 1989). 
established at the top of society. ${ }^{133}$ In fact, such ideas were prevalent among all groups within the population. This is hinted at by Michael Sonenscher, who linked the way the Jacobins organized their clubs to the "democracy of the workshop" in France during the French Revolution. ${ }^{134}$

An interesting figure who can illustrate the link between labour and politics in the seventeenth century is Thomas Asselijn (c. 1620-1670). He was a poor dyer, and although he was officially a free artisan, he was no doubt dependent on the large textile employers. In his spare time he was also a self-educated playwright. Protest was an important theme in his works, especially in his play about Mas Anjello, the leader of a revolt in Naples in 1653, published in $1668 .{ }^{135}$

\section{International aspects}

The working-class culture that existed in Holland from the Middle Ages to the eighteenth century was by no means exceptional. This has been made clear by recent studies of eighteenth-century Germany, France and England. The French shearers of Sedans, for example, did not differ from their colleagues in Leiden. ${ }^{136}$ In 1750 during a meeting they called a cessation générale (a strike), they chose députés (delegates), and non-strikers were declared sale (foul). In other trades such cabales (intrigues) also occurred regularly. They lasted from several hours to several days. Sometimes a bourse commune (strike fund) was set up. Unlike in Holland though, journeymen had permanent organizations. These were called compagnonnages and frèreries. Frèreries were religious in origin and were more loosely organized than compagnonnages. Both forms of union were officially forbidden but were tolerated in practice. Their social purpose was more important than their defence of common interest, and therefore they can only to some extent be compared with modern labour unions. The compagnonnages particularly had elaborate rituals including the tour de France journeymen had to make in order to finish their training. The French Revolution brought little change. Le Chapelier's new law only revived the old prohibitions in word; in practice the unions were still tolerated, and

${ }^{133}$ Wolfgang Jäger, "Mehrheit, Minderheit, Majorität, Minorität", in Geschichtliche Grundbegriffe, III (Stuttgart, 1982), pp. 1021-1062.

${ }_{134}$ Michael Sonenscher, "The Sans-culottes of the Year II: Rethinking the Language of Labour in Revolutionary France", Social History, 9 (1984), pp. 301-328.

${ }_{135}$ Marijke Eleonore Meijer Drees, De treurspelen van Thomas Asselijn (ca. 1620-1701) (Enschede, 1989).

${ }_{136}$ G. Gayot, "La longue insolence des tondeurs de draps dans la manufacture de Sedan au XVIIIe siècle", Revue du Nord, LXVIII (1981), pp. 105-134. See also the literature mentioned in notes 6 and 9 . 
survived to form a link with the modern labour movement of the nineteenth century. The nature of this transformation, however, is still open to debate. ${ }^{137}$

In England, although there were no compagnonnages, workers were also well organized. ${ }^{138}$ Like in Holland, many labourers had "box clubs". These were societies that paid sums of money to its contributing members in cases of illness or death, but they also did much more. The London tailors, for instance, had in 1700 five clubs joined together by a central union. Fifty years later a national federation was formed comprising fifty clubs represented by delegates and a board of governors. These clubs could serve as centres for protest, and strikes were anything but exceptional. In many other trades strikes were also common. Like in Holland and France nonstrikers were kept under control by the threat of being declared "foul" and punished with fines. Rituals played a role, in which drinking together had a special meaning. Strikes were often accompanied by merry making, and tumultuous marches, like the demonstration in London in 1768 of coal heavers which was preceded by a flag bearer, drummers and violinists. The Combination Acts of 1799 and 1800 had made such activities unlawful, but they left the original box clubs as such undisturbed. In England, like in France, there was a degree of continuity between the eighteenth-century workers' culture and those of the nineteenth and twentieth centuries; and like in France, the precise nature of this continuity still invites further research.

In eighteenth-century Germany the situation was not very different. ${ }^{139}$ Protests among workers were quite common. Discipline was maintained, as in France and Holland, by declaring non-strikers unehrlich (foul). In the first half of the eighteenth century, German journeymen had strong organizations with frequent contacts at a regional level. Rituals such as the Gesundheit Trinken and the sword dances of the shoemakers were important. In the second half of the eighteenth century repression transformed this apparently favourable position of the workers. In Germany there was a distinct discontinuity between this old workers' tradition and the modern labour movement. Germany industrialized late in the nineteenth century, and imported the strike from England and France.

${ }^{137}$ Sewell, Work and Revolution in France, and Lynn Hunt and George Sheridan, "Corporatism, Association and the Language of Labor in France, 1750-1850", Journal of Modern History, 58 (1986), pp. 813-844.

${ }_{138}$ Dobson, Masters and Journeymen, and Rule, The experience of labour in 18th-century industry. For a more general picture see John Rule, The Labouring Classes in Early Industrial England, 1750-1850 (London, 1986).

${ }^{139}$ Griessinger, Das symbolische Kapital der Ehre; Elkar, Deutsches Handwerk in Spätmittelalter und fruher Neuzeit, and Thamer, "On the Use and Abuse of Handicraft". 
There are many resemblances in the forms of organizations and protests in these three countries. Everywhere journeymen had some form of organization, they had their own rituals, they held meetings, they voted to go on strike, and they had a system, based on honour and dishonour, which enforced solidarity. This workers' culture was not bound by national borders. In other words, there seems to have been, at least until the middle of the eighteenth century, a common working-class culture in the northwestern part of Europe. The Dutch case supports this observation. Dutch workers had informal organizations, held meetings, voted to call strikes, had their drinking rituals, and similarly enforced solidarity by dishonouring colleagues. What is even more remarkable is that in Holland, despite occasional friction, immigrants from various countries largely cooperated. The shearers who were arrested during a protest in Leiden in 1644 came from Germany, France, and England. The leader of a strike of shearers in Amsterdam in 1691 came from Germany. The weavers protesting in Leiden in 1724 came from France.

There were differences too however. Firstly there was the low level of organization. In Holland, organizations of journeymen were from relatively early on successfully repressed by the authorities, and repression in Holland was more successful than elsewhere. Already in the seventeenth century the uitgang had been brought under control by both the authorities and the manufacturers. And there never was anything in Holland that can be compared with the French compagnonnages or even the English box clubs. The social basis for protest and organization among Dutch workers remained rooted in informal networks. Rituals seem to have had less importance for them: there were no elaborate rites, as in the French compagnonnages, nor German sword dances. In Holland protest in general had a much less festive character. They were much more straightforward and goal oriented. ${ }^{140}$ Another remarkable feature is that some trades which had in other countries a reputation for being volatile, such as the shoemakers and tailors in England and Germany, were seemingly subdued in Holland. There also seem to have been differences in the aims of their protests. Elsewhere issues of corporate rights and honour were often more important than wages. In Holland wages were as a rule often the central issue. In short, although Dutch workers did not succeed in establishing permanent organizations, their protests were characterized by behaviour that can be considered modern compared with what was prevalent elsewhere.

140 The province of Zeeland offers a unique example of a conflict which was fought out in pamphlets. Benjamin Cateau, Goede raad aan Jan Poley (Vlissingen, 1786). The pamphlets are not preserved, but the case is mentioned in the Nieuw Nederlandsch Biografisch Woordenboek, 10 vols (Leiden, 1911-1937), VII, p. 284. 
In France and England there was some degree of continuity between the old labour culture of the eighteenth century, and the modern labour movement. In Germany, on the other hand, there was a discontinuity. Here repression had taken its effect, and by the end of the eighteenth century little was left of the old militancy. Furthermore, Germany industrialized late in the nineteenth century, and the new labour movement that accompanied this process took its inspiration from France and England, where both modern industry and a labour movement were already established. The German word Streik even has its origins in the English language.

Developments in the Netherlands resembled those in Germany. In Holland workers also became less militant after around 1750, not because of greater repression, but mainly because of industrial decline. Modern industry appeared in Holland only in the last quarter of the nineteenth century. The first modern strike was that of the shipwrights in Amsterdam in 1869-1870. ${ }^{141}$ By then workers had forgotten all about the uitscheiding and the uitgang of the previous centuries. Like the Germans, they had to look to France and England for examples of how to organize a labour movement. The word uitscheiding had disappeared from the Dutch language, the workers, the authorities and the press used the French grève or the English "strike" for what they thought of as a new type of protest. In fact, this was a case of an old Dutch word being reintroduced into the language since the English word "strike" was originally a Dutch seaman's term, strijken, meaning striking the sails of a ship. It was not until around 1900 that a Dutch word for strike found general acceptance: staking. ${ }^{142}$ Although in the twentieth century Holland preserved its reputation of having a low incidence of strikes, at least from then on it again fitted into a general European pattern.

\section{Some conclusions}

The history of labour relations in Holland can be broken down into three periods: the late Middle Ages (fifteenth century), the time of the Republic (1600-1770), and the modern period (since 1870). Labour conflicts before the nineteenth century are really only well documented for the textile industry. They suggest that the first period was characterized by the use of

141 Algemene Geschiedenis der Nederlanden, 15 vols (Haarlem, 1977-1983), XII pp. 137 and 162. The lack of strike activity before that year is confirmed by J. MacLean, "Arbeidsconflicten in de periode 1813-1872", Tijdschrift voor Sociale Geschiedenis, 16 (1979), pp. 292-313.

${ }^{142}$ In her memoirs Aletta Jacobs writes that she did not recollect there being strikes during her youth, in the middle of the nineteenth century: Aletta H. Jacobs, Herinneringen (Nijmegen, 1978), p. 11. On the word staking see Woordenboek der Nederlandsche Taal, XV ('s-Gravenhage, 1940), pp. 502-503. 
the uitgang, during which the workers left the town where they were employed. The second period was characterized by the uitscheiding; both were forms of labour withdrawal. The uitscheiding resembled the modern strike in many respects. Although the sixteenth century was relatively untroubled by labour protest, there was a continuity between the first two periods. The period $1770-1870$, on the contrary, marks a discontinuity.

In the late Middle Ages and the time of the Republic, Dutch workers never succeeded in establishing permanent organizations, unlike workers in other European countries. This was probably the result of efficient repression on the part of the authorities. If necessary the authorities were also prepared to take armed action against strikes and other forms of labour protest. Nevertheless, within the textile industry a system of unofficial internal methods of resolving conflicts developed. The democratic procedures used during periods of labour protest could easily be transferred into a political context, as was the case during the political disturbances in the years $1747-1750$.

Although some rituals existed among Dutch workers, they were not so fully developed as in other countries. And although personal honour was an important aspect of Dutch labour culture, it was not as central as in Germany for instance. In many conflicts the aims of the workers were quite simply better wages. This all makes labour relations in Holland look somewhat more modern than those in the surrounding countries. The disappearance of workers' protests during the second half of the eighteenth century forms a striking contrast with the results of recent historical research in England and France. In the nineteenth century the modern labour movement in Holland was largely established along the lines of those in countries which had industrialized earlier. In the history of labour relations in preindustrial Holland the late eighteenth century was therefore more a sad epilogue than a period of renewal. 